\title{
Does tree harvesting in streamside management zones adversely affect stream turbidity?-preliminary observations from an Australian case study
}

\author{
Daniel G. Neary • Philip J. Smethurst • \\ Brenda R. Baillie • Kevin C. Petrone • \\ William E. Cotching • Craig C. Baillie
}

Received: 15 October 2009/Accepted: 29 March 2010/Published online: 23 April 2010

(C) The Author(s) 2010. This article is published with open access at Springerlink.com

\begin{abstract}
Purpose In Australia, farmers and natural resource managers are striving to enhance environmental outcomes at farm and catchment scales by planting streamside management zones (SMZs) on farms with trees and other perennial vegetation. Lack of sound information on and funding for
\end{abstract}

Responsible editor: Ellen Petticrew

\section{G. Neary}

CSIRO Sustainable Ecosystems,

Private Bag 12,

Hobart, TAS 7001, Australia

D. G. Neary $(\bowtie)$

US Forest Service, Rocky Mountain Research Station,

2500 South Pine Knoll Drive,

Flagstaff, AZ 86001, USA

e-mail: dneary@fs.fed.us

P. J. Smethurst • C. C. Baillie

CSIRO Sustainable Ecosystems, CRC for Forestry,

and Landscape Logic CERF Hub,

Private Bag 12,

Hobart, TAS 7001, Australia

B. R. Baillie

SCION,

Private Bag 3020,

Rotorua 3010, New Zealand

\section{K. C. Petrone}

CSIRO Land and Water and Landscape Logic CERF Hub,

Private Bag 5,

Wembley, WA 6009, Australia

\section{W. E. Cotching}

University of Tasmania, Tasmanian Institute of Agricultural

Research, CSIRO Sustainable Ecosystems

and Landscape Logic CERF Hub,

P.O. Box 3523, Burnie, TAS 7320, Australia establishing and managing trees in SMZs is hindering widescale adoption of this practice. Australian Codes of Forest Practice discourage or prevent harvesting of trees in SMZs of perennial streams. One concern is the potential effect of tree harvesting in SMZs on delivery of sediment to adjacent streams. The aims of this paper were to summarize the literature relevant to this concern and, in one case study in an agricultural context, to determine the effects on turbidity of harvesting a SMZ plantation.

Materials and methods Information was sourced from published studies that reported on impacts of tree harvesting inside SMZs. In addition, a study was conducted in Tasmania, Australia, to evaluate the water quality benefits of a SMZ and the effects of tree harvesting in this zone. This case study consisted of a 20-year-old Eucalyptus nitens pulpwood plantation in a SMZ of an intermittent stream that was harvested according to the state Code of Forest Practice. A machinery exclusion zone immediately adjacent to the stream limited machinery traffic. Ground cover and water quality pre- and postharvesting were measured to identify the major sources of sediment in this headwater catchment, and to determine the effect of tree harvesting.

Results and discussion Literature indicates that tree harvesting in SMZs is an accepted practice in the USA, New Zealand, and Germany, if conducted carefully, i.e., using best management practices (BMPs). Negative effects of this practice on water quality, in- and near-stream habitat, and biodiversity have been recorded, but these effects were generally minor or transitory. Tree harvesting in the Tasmanian study resulted in minimal mineral soil exposure and increased surface roughness. Postharvesting turbidity levels in streamflow were similar to preharvest levels $(<2.5$ nephelometric turbidity units exiting the catchment). Much 
more significant sources of sediment were a road, a dam that was accessible to cattle, and a cultivated paddock. These sources led to turbidities of c. 300 NTUs in a dam immediately below these points and above the harvested stream reach during a storm in late June 2009. In-stream dams, installed many years earlier to store water for stock and irrigation, acted as very effective sediment traps.

Conclusions The SMZs and other BMPs used in agroforestry landscapes are effective at protecting water quality. Forest harvesting operations can be conducted in SMZs without increasing stream turbidity, if existing BMPs are followed.

Keywords Agriculture - Buffer - Forest - Riparian · Sediment $\cdot$ Streamside management zones .

Tree harvesting $\cdot$ Turbidity $\cdot$ Water quality

\section{Introduction}

\subsection{Background}

Streamside management zones (SMZs) have been used for decades as buffers to mitigate the potential adverse effects of agricultural and silvicultural practices on adjacent surface water quality (Cooper et al. 1987; Comerford et al. 1992; Correll 2005). The concept is quite old, dating back to the 1700s (Lee et al. 2004). Streamside management zones came into common use in the 1960s to improve water quality by functioning as barriers or treatment zones to protect adjoining water resources from disturbances associated with agriculture and forestry (Fig. 1). They have been identified as one of the most effective tools for reducing nonpoint source pollution from managed landscapes (Phillips 1989).

In agricultural and forestry landscapes, the concept of a SMZ implies active management during some or all phases of the zone's life cycle. This includes areas that may be actively designated as "undisturbed" trees, shrubs, or herbaceous plants. These zones could have management plans that provide for no or infrequent disturbances such as prescribed fire, grazing, or tree harvesting needed to maintain them in a vegetative condition conducive to achieving the overall objectives of the SMZ. The key to the concept of a SMZ is that it is actively managed rather than passively left as a reserve that is allowed to develop toward a semistable successional state.

\subsection{Terminology}

The terminology associated with these special landscape units is a source of confusion. Understanding any concept and its accompanying literature is based on the shared knowledge of the descriptive terminology used. Therefore, it is appropriate to discuss the terms used in the literature since there is a lack of uniformity in how these near-stream landscape units are named.

Buffer strip is a term commonly used to describe the transition between two different land uses where one land use, the buffer, mitigates the effects of the other (Karr and Schlosser 1978; Comerford et al. 1992). Buffer strips reduce runoff and associated pollutant loads to streams, lakes, and wetlands via filtration, deposition, infiltration, adsorption, uptake, and decay processes.

Filter strip is a term often used synonymously with "buffer strip". Its focus is on the function of physically filtering pollutants derived from upland areas of landscapes. Filter strips are usually viewed as zones to remove sediment from runoff (Cooper et al. 1987), but they will also filter out subsurface nutrients such as nitrate nitrogen if they are wide enough (Lowrance et al. 1985). Filter strips are most often used at field edges, but they can also function well along streams.

Riparian zone has variants in the terms "Riparian Buffer" and "Riparian Management Zone". Technically, riparian zones are those that meet the strict definition of "riparian" elucidated by (Mitsch and Gosselink 2007). Their definition is: The riparian zone of a river, stream, or other body of water is the land adjacent to that body of water that is, at least periodically, influenced by flooding. Riparian zones are highly productive ecotones or transition zones between upland and aquatic ecosystems that are under the influence of flooding and shallow groundwater. They can vary from a few to hundreds of meters in width. Often, the term "Riparian Management Zone" is used to broaden the concept to that of a buffer (Lowrance et al. 1985). Riparian management zones and buffers refer to managementdesignated areas that may or may not include all the components of the riparian zone, and may also include upland areas.

Greenways and grassed waterways are specialized grass or herbaceous plant zones along first- and second-order drainage areas in agricultural landscapes (USDA ARS 1987). They are sometimes used in forested areas, but not very frequently. In general, grassed waterways typically carry concentrated flows but have a high potential for reducing runoff volume and velocity, sediment transport, and chemicals coming from agricultural watersheds through sediment detention and infiltration functions (Fiener and Auerswald 2003).

Wetland is a term often used interchangeably, and sometimes inappropriately, with riparian. Wetlands are discussed in detail by (Mitsch and Gosselink 2007). This landform includes 15 different popular terms such as bog, fen, marsh, moor, swamp, bottomland, etc. Although the term also describes land that is transitional between 
Fig. 1 Streamside management zone along the Tarawera River, New Zealand (photo by B.R. Baillie, Scion,

New Zealand)

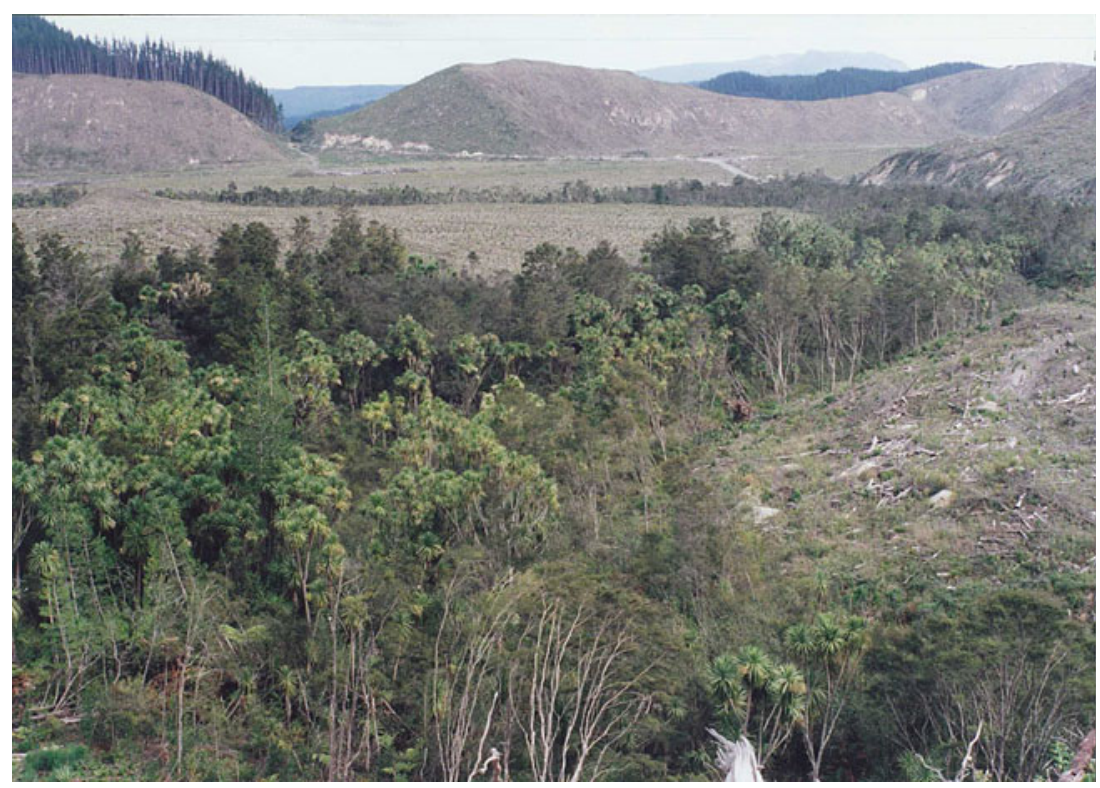

terrestrial and aquatic ecosystems, there are a number of distinctions that set wetlands apart from other landscape units. In the classification of USA wetlands, the term is defined as referring to lands where the water table is at or near the surface or the land is covered by shallow water (Cowardin et al. 1979; Cowardin and Golet 1995).

Streamside management zones are landscape units determined by various combinations of economic, ecological, and regulatory factors (Williams et al. 2003). This can include riparian as well as upland areas (Phillips et al. 1999). The term encompasses all potential functions and management objectives for landscape units adjacent to streams and of a width that is context sensitive. Thus, the term is not tied to the hydrologically functional area of the riparian zone since it can include parts of upland areas, and it includes functions other than buffering. For these reasons, it is preferable to define the managed landscape units along streams and other bodies of water as SMZs (Fig. 2).

Machinery Exclusion Zone (MEZ) is an area adjacent to streams where machine operation is prohibited. It is often $10 \mathrm{~m}$ in width but can be much larger depending on SMZ design and constraints. Machinery is allowed to grapple or cable-skid trees within the MEZ, but it cannot move its wheels or tracks into the zone.

Best Management Practices (BMPs) is a term used in many domains, e.g., from accounting and tourism to forestry, that implies there is a widely acceptable combination of operational activities that under most conditions ensure desirable outcomes. In forestry and farming, the term usually refers to practical and economic operational procedures and practices that eliminate or keep risks to environmental quality at an acceptably low level. For example, one BMP for forestry operations is to keep machinery out of waterways, minimize stream crossings, and establish sediment control treatments such as gabions, sediment fences, straw bales, or wattles, and ditch-line diversions in order to minimize sediment runoff at stream crossings. Not all BMPs are accepted by all stakeholder groups as providing the desired environmental outcome. The term BMP can be misleading if best is understood to imply that better practices do not exist, but this is not the way most regulators, managers, or practitioners intend use of the term, because there is always the possibility that new scientific knowledge and practical experience can be used to improve a currently accepted BMP.

Codes of Practice are collections of BMPs that are, if compulsory, prescribed in regulations and guidelines, and therefore require compliance. Codes of Practice may be applicable to all or any combination of target groups, e.g., forestry operations on public and private land, and in small or large areas. Forest practices in many developed countries are regulated in this manner. However, BMPs and Codes of Practice can also be voluntarily developed and adopted, which are common in the agricultural sector.

\subsection{Streamside management zone functions}

Streamside management zones provide a number of important functions in ecosystems (Welsch 1991, Table 1). They fall into the broad biophysical categories of water quality protection, streamflow moderation, geomorphic stability, flora and fauna benefits, and atmosphere improvement. While these functions are important, SMZs in an agricultural and forestry landscape can also provide important socioeconomic functions.

The main water quality functions provided by SMZs are maintenance of low temperatures, filtration of nutrients and sediments, detention of contaminants, uptake of nutrients in 
Fig. 2 Hypothetical

geomorphic and management relationships between stream, riparian zone, SMZ, and upland areas. A SMZ might also be narrower than the riparian zone. Dashed lines delineate the natural zone influenced by saturation or flooding. Solid lines are management delineations

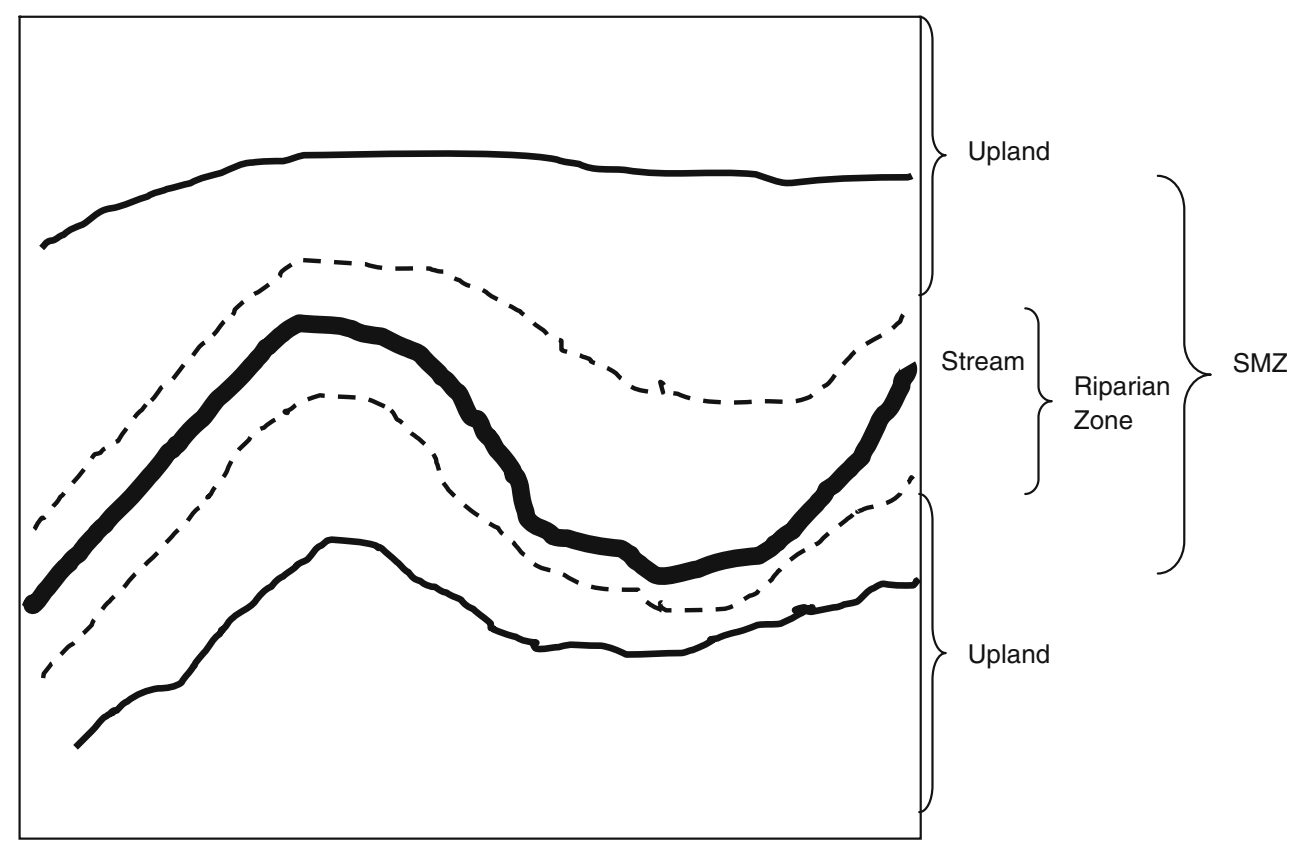

plants, transformations of nitrogen compounds and pesticides, reduction of macrophyte growth, and delivery of organic matter as a source of energy and nutrients for stream biota (see Table 1, Schultz et al. 2009). Sediment detention is a commonly sought after function of SMZs, and, where trees are included in SMZs, cooler stream water is also an important outcome due to shading and prevention of stream flow solar heating (Collier et al. 2001). Streamside management zones are viewed as a valuable intervention strategy to prevent contamination of streams with pesticide residues, although they are not entirely effective (Neary et al. 1993; Davies and Nelson 1994; Neary and Michael 1996; Maltby and Hills 2008).

Streamside management zones have important hydrologic and geomorphic functions. Although SMZ vegetation uses water, the zone is also important for storing water for release later as baseflow (Schultz et al. 2009). A SMZ can also retain more runoff than grazed pastures they replace, because SMZs containing trees result in higher infiltration rates. Overbank flows are important for reducing flood peaks by spreading water over wider cross sections. Streamside management zone vegetation can reduce channel erosion by stabilizing banks. However, there are some conditions where vegetation along the edge of channels can contribute to bank scouring and erosion (Ffolliott et al. 2003). Tree stems adjacent to channels can cause turbulent vortices which cut into stream banks, adding to the normal flood-related erosion.

An important function of SMZs is providing terrestrial and aquatic habitat for both flora and fauna. This function contributes greatly to landscape biodiversity, especially in semiarid environments (Baker et al. 2003). Streamside management zones provide important landscape connec- tions and cover for terrestrial wildlife as well as habitats for aquatic species.

The social and economic benefits of SMZs in agroforestry landscapes have been recognized as very important for agriculture (Correll 2005, see Table 1). Some of the key functions are livestock and crop shelter, forage and water sources, livestock safety, aiding farm certification, providing a source of wood and additional farm income, and potential carbon sequestration (Specht and West 2003). The potential for SMZs to provide a future wood supply and source of income for farmers could develop as one of several major incentives for farmers to establish tree plantations along drainages, streams, lakes, and wetlands. In the future, these plantations will need to be harvested in an environmentally sound manner. Existing BMPs in some countries are designed to achieve that goal, but the practice is currently discouraged in Australia (Smethurst 2008).

It should be noted that temporary removal of trees from SMZs may produce other adverse effects than sediment generation that would also need evaluation. These include effects such as water temperature increases, bank stability deterioration, channel morphology changes, declines in inputs of woody debris for habitat and of leaf litter as an aquatic food resource, increased algal growth in response to light, and changes in other water quality parameters such as phosphorus and nitrogen. Rapid reforestation of harvested SMZs is likely to reduce both the magnitude and the duration of these changes.

\subsection{Forestry practices}

Tree plantations on farms are a large potential resource for achieving a variety of catchment functions and benefits. 
Table 1 Summary of SMZ functions adapted from Comerford et al. (1992), Correll (2005), Lowrance et al. (1997), and Mander et al. (2005)
Not all of these functions are achieved in every case where a SMZ is used

\begin{tabular}{|c|c|c|}
\hline Category & Components & Functions \\
\hline \multirow[t]{6}{*}{ Water quality protection } & Temperature & Low temperature maintenance \\
\hline & Sediment & Filtration and deposition \\
\hline & Contaminants & Detention, adsorption, degradation \\
\hline & Nutrients & Detention in sediments \\
\hline & & Plant uptake and transformations \\
\hline & Macrophytes & Reduce growth \\
\hline \multirow[t]{4}{*}{ Streamflow moderation } & Baseflow & Water storage \\
\hline & & Flow maintenance during dry periods \\
\hline & Floods & Water storage \\
\hline & & Peakflow reduction \\
\hline \multirow[t]{4}{*}{ Geomorphic stability } & Streambanks & Bank stabilization \\
\hline & & Stream erosion reduction \\
\hline & Streambeds & Scour reduction \\
\hline & Uplands & Wind erosion reduction \\
\hline \multirow[t]{8}{*}{ Flora and fauna benefits } & Terrestrial habitat & Create or maintain productive habitats \\
\hline & & Provide movement corridors and connectivity \\
\hline & & Enhance landscape biodiversity \\
\hline & Aquatic habitat & Moderate temperature \\
\hline & & Provide stable substrates \\
\hline & & Maintain streamflow \\
\hline & & Create new habitats \\
\hline & Food webs & Provide organic energy source \\
\hline \multirow[t]{2}{*}{ Atmosphere improvement } & Air quality & Filter pollutants and odors \\
\hline & & Improve adjacent microclimate \\
\hline \multirow[t]{10}{*}{ Social and economic benefits } & Floods & Reduce damaging peakflows \\
\hline & Esthetics & Provide vegetation screens and landscape diversity \\
\hline & Real estate & Improve farm property financial value \\
\hline & Environment & Increase carbon sequestration and credits \\
\hline & Recreation & Provide recreational sites \\
\hline & Agriculture & Provide livestock shelter \\
\hline & & Provide livestock forage, water, and security \\
\hline & & Aid certification of farm products \\
\hline & & Provide a source of wood products and income \\
\hline & & Conserve soil resources \\
\hline
\end{tabular}

The farm area in Australia, combining modified pastures and cropping areas, amounts to 49.7 million hectares (BRS 2009a). Utilizing just $1 \%$ of that area for future tree plantings would almost double the nation's plantation forest estate and provide the space for national commitments to carbon sequestration (DSE 2008).

In the Yan Yan Gurt catchment in Victoria, a large proportion of farmers have adopted the practice of establishing forested SMZs during the past two decades, and harvesting has commenced (Reid and Burk 2002). This model merits consideration nationally as the country attempts to triple its forest plantation estate between 1997 and 2020 to meet wood production and carbon sequestration goals (Thompson 2008; BRS 2009b). Streamside management zones on farmland using commercial or noncommercial trees and other vegetation are also encouraged for improving soil, water, and biodiversity values (Robins 2002). However, water use by plantations is increasingly under scrutiny, and it is a deterrent in some cases where other uses of a scarce water resource have a real or perceived higher value (Keenan et al. 2004). This interest in plantation development comes at a time when there is also a need to increase food production to meet the demands of population growth (FAO 2008). Hence, the benefits of tree plantations of potentially improving water quality and providing other benefits needs to be weighed against their potential to compromise the availability of water for municipal supplies and food production. There is 
a large body of literature on the effects of tree cutting on water yield and quality (Neary 2002). The science needs now, in particular, are evaluations of the impacts of SMZ tree harvesting on water quality across and between physiographic regions and replicated within regions.

Although Codes of Forest Practice in some jurisdictions apply to commercial forestry operations on all land tenures, e.g., in the state of Tasmania, their applicability to SMZs on cleared farmland is not clearly laid out, or in some cases, is discouraging because harvesting is not permitted (Smethurst 2008). In most jurisdictions, this practice is exempt from Code provisions if annual harvest areas are very small, e.g., less than 1 ha. There is recognition in at least one Code that these provisions may change as new knowledge becomes available (Forest Practices 2000, p. 84), and most Codes have a five-yearly review cycle.

In a plantation cycle, most concerns about potential effects on water quality arise during establishment, harvesting, or tending operations that include major soil disturbance or the application of fertilizers, herbicides, or pesticides. Hence, these operations are foci within Codes of Practice. For example, in the Tasmanian Forest Practices Code, in relation to reforestation of pasture land (Forest Practices 2000, p. 81-84; currently being revised), plantation establishment and harvesting in SMZs are permitted subject to:

- No establishment within $2 \mathrm{~m}$ of a stream bank

- Machinery exclusion provisions

- Restrictions on cultivation

- Restrictions on the use of chemicals

- Prohibition of tree harvesting within $10 \mathrm{~m}$ of a bank of a permanent stream

The latter restriction, meant for broad-scale plantation forestry, is problematic in an agroforestry system where SMZ forests are smaller. Farmers might prefer to establish plantations next to streams, and such restrictions could affect harvesting economics. The $10-\mathrm{m}$ exclusion in the Tasmanian Code (Forest Practices 2000) was based on practical considerations and conservative estimates of a distance needed to assure adequate water quality, but not on actual field monitoring of water quality during and after tree harvesting in SMZs using BMPs.

1.5 Published information on SMZ harvesting in relation to water quality

Sediment is an important water quality parameter, since higher than normal levels can harm aquatic organisms and habitats and render water unacceptable for domestic or recreation purposes. Sediment yields after forest harvesting are highly variable depending on such factors as soils, climate, topography, ground cover, and watershed condition. Although sediment yields often increase after harvesting due to the physical disturbance that exposes soil to erosion processes, these increases are usually transient due to vegetation regrowth, and are mitigated by slash and litter retention and other aspects of surface roughness. However, the duration of sediment increases above predisturbance conditions can vary considerably. Beschta (1978) reported effects lasting 6 years after logging, while Lynch and Corbett (1990) saw effects out to 10 years. Neither study lasted long enough to document recovery to predisturbance conditions.

The largest increases in sedimentation documented in the literature have been associated with postharvest mechanical site preparation in the absence of SMZs (Beasley 1979), or with slope instability (O'Loughlin and Pearce 1976), road construction (Swanson et al. 1986), or highly erosive soils (Beasley and Granillo 1988). Best management practices are most effective on sediment when properly planned and implemented prior to, during, and after harvesting. Most of these guidelines relate to designing, constructing, and maintaining major access roads, logging roads, skid trails, and landings (Binkley and Brown 1993). These areas are the primary sources for 90 percent of the sediment generated by harvesting (Reid and Dunne 1984; Swift 1986). The underlying principles of BMP guidelines in this context are to minimize disturbances in SMZs, to reduce the erosive power of runoff from bare road surfaces, and to maintain the normally high infiltration capacity of forest soils.

Sediment movement to streams is an ongoing environmental concern in managed forest watersheds, but it also occurs naturally without active management. Watersheds vary greatly in their natural sediment load characteristics. Both natural and anthropogenic sediment deposits can be re-entrained after initial deposition in ephemeral or perennial stream channels, and move downstream for long time periods ( $>100$ years) and distances. The cumulative effects of erosion and sedimentation that occurred centuries ago from agriculture or forestry can present land managers with many challenges such as channel bank collapse, tunnel erosion, and channel sediment transport to sensitive water resources (Neary 2002; DeBano et al. 2005).

Reference sediment yield baselines have been discussed by (Neary and Michael 1996; Neary 2002; DeBano et al. 2005). Natural erosion rates (geologic erosion) for undisturbed forests in the western USA of $<0.01$ to $5.53 \mathrm{Mg} \mathrm{ha}^{-1}$ year $^{-1}$ are generally higher than eastern US yields of 0.1 to $0.2 \mathrm{Mg} \mathrm{ha}^{-1}$ year $^{-1}$, but do not approach the upper limit of geologic erosion $\left(15 \mathrm{Mg} \mathrm{ha}^{-1}\right.$ year $^{-1}$, Schumm and Harvey 1982). Australia's geologic erosion rates range from 0.04 to $0.86 \mathrm{Mg} \mathrm{ha}^{-1}$ year $^{-1}$ (Wasson et al. 1996). The measured differences at both continental and local scales are due to natural site factors such as soil and geologic erosivity, rates of geologic uplift, tectonic activity, slope, rainfall amount 
and intensity, vegetation density and percent cover, and fire frequency. Landscape-disturbing activities such as mechanical site preparation (15 $\mathrm{Mg} \mathrm{ha}{ }^{-1}$ year $^{-1}$; Neary and Hornbeck 1994), agriculture (560 Mg ha ${ }^{-1}$ year $^{-1}$; Larson et al. 1983), and road construction (140 Mg ha ${ }^{-1}$ year $^{-1}$; Swift 1986; Binkley and Brown 1993) produce the most sediment loss and can match or exceed the upper rate of geologic erosion. Erosion rates can be as high as $1,000 \mathrm{Mg} \mathrm{ha}{ }^{-1}$ year $^{-1}$ in small gullied basins, and along with channel banks, they are the main sources of sediment for Australian rivers (Wasson 1994; Prosser et al. 2001). Roads, including tree harvesting access roads and skid tracks, are particularly problematic and chronic contributors of sediments to streams.

Variation in suspended sediment concentration can be quite large both within and between individual catchments and regions (Binkley and Brown 1993). Most undisturbed forested catchments have suspended solid concentrations $<5.0 \mathrm{mg} \mathrm{L}^{-1}$ and stormflow peaks $>100 \mathrm{mg} \mathrm{L}^{-1}$, but some routinely average higher than $20 \mathrm{mg} \mathrm{L}^{-1}$. Storm runoff from steep watersheds with highly erosive soils can have average suspended solids concentrations $>400 \mathrm{mg} \mathrm{L}^{-1}$ (Beasley 1979). Responses of forested watersheds harvested without SMZs can be in the range of $<2$ to 43 times reference or pretreatment conditions (Binkley and Brown 1993).

The effectiveness of SMZs in filtering out sediment from storm runoff has been demonstrated in a number of studies (e.g., (Arthur et al. 1998; Dosskey 2001; Helmers et al. 2005; Loch et al. 1999; McKergow et al. 2003; McKergow et al. 2006)). Sediment removals of $90 \%$ or more have been measured, and reductions in flow weighted mean suspended sediment concentrations of an order of magnitude have been documented (148 to $13 \mathrm{mg} \mathrm{L}^{-1}$, McKergow et al. 2003). So, it is very clear that SMZs can work well in protecting or improving water quality. The big question is: "Can tree stands in SMZs be harvested without causing a significant deterioration in water quality and other important functions?" There are a limited number of published studies in Australia or New Zealand that address this question.

Hemstad et al. (2008) reported on fish habitat changes after several thinning treatments in a mixed hardwood forest with a SMZ. Reference areas had no tree felling at all. Riparian reference sites had upland areas that were clear-felled with a shortwood cut-to-length (CTL) system, but they retained a 30-m no-cut buffer zone (Mattson et al. 2000; Palik et al. 2000).

Cut-to-length logging is a mechanized harvesting system in which trees are delimbed and cut to specified lengths (usually $3 \mathrm{~m}$ ) directly at the tree stump. CTL is typically a two-machine operation with a harvester felling, delimbing, and cutting trees and a forwarder transporting the logs from the felling to a landing. The CTL riparian thinning treatment involved upland clear-felling and SMZ harvesting to a residual basal area of
$12.3 \mathrm{~m}^{2} \mathrm{ha}^{-1}$. The final treatment was a whole tree-length (WTL) harvesting where the adjacent upland was clear-felled and the SMZ was thinned to the same residual basal area as the CTL treatment. In WTL, logging trees are felled, delimbed, topped, and moved to a landing without being cut into smaller lengths. (Hemstad et al. 2008) measured a small $(15 \%)$ increase in streambed fine sediments and gravel embeddedness after harvesting. However, the sediment increase was catchment-wide in all stream reaches and involved the uncut reference reaches as well as the stream reaches that had SMZ harvesting. The effect was attributed to sediment washing off roads and stream crossings and into stream channels, not sediment derived from SMZ harvesting operations. This result points out the role of roads in producing much of the postharvest sediment yield observed in forested catchments. Roads have been broadly recognized as important contributors to stream sediment loads (e.g., Beschta 1978; Swift 1986; Ziemer and Ryan 2000).

In another study, a coastal plain swamp (riparian zone) forest in North Carolina was clear-felled in May 1998, leaving a 10-m wide uncut portion of the SMZ as a buffer (Ensign and Mallin 2001). The harvested area was along the lower end of a $479-\mathrm{km}^{2}$ catchment. A significant increase in total suspended solids was measured in the harvested catchment during rainfall in June, July, and August after harvesting. Compared to a nearby uncut reference catchment, suspended solids were consistently 3 to $10 \mathrm{mg} \mathrm{L}^{-1}$ higher in the logged catchment during that 3-month period. One peak of 111 nephelometric turbidity units (NTUs) was measured in the treated catchment during the first month after clear-felling. In contrast, extreme rainfall during Hurricane Bonnie in late August 1998 did not produce a notable effect on total suspended solids in either catchment. Stream samples collected 8 days after the hurricane landfall and $85 \mathrm{~mm}$ of rain did not show any notable impact to the total suspended solids as a result of the storm. Turbidity in the harvested area was not significantly different from the uncut reference catchment, although it did rise from 6 to 14 NTUs due to the hurricane. This was not a significant rise in NTU level, but it demonstrates that harvesting in wide riparian zones can lead to at least small and transient increases in turbidity even if BMPs exclude SMZ harvesting.

Gomi et al. (2006) studied the effects of logging lowland tropical rainforest in Butik Tarek Experimental Watershed in Malaysia that included 20-m SMZs. Catchments (14 to 38 ha) included a reference site with no harvest (C1), a 20-m SMZ (C2), a 20-m SMZ with a high road density and in close proximity to the SMZ (C2T), and a SMZ partial harvest (C3). Catchment areas outside the SMZs were clearcut and logs extracted by skidders and log trucks. There was no significant difference in sediment delivery to the Butik Tarek stream in catchments $\mathrm{C} 1$ and $\mathrm{C} 2$. Catchments $\mathrm{C} 2 \mathrm{~T}$ and $\mathrm{C} 3$ produced six and five times the sediment volume into channels, respective- 
ly, than the $\mathrm{C} 1$ catchment. Roads and skid trails in $\mathrm{C} 2 \mathrm{~T}$ and $\mathrm{C} 3$ with steep gradients $(>20 \%)$ and a high degree of connectivity to the catchment channels were responsible for the high sediment delivery to the Butik Tarek stream, not the treefelling operation per se, as observed, for example, by Sidle et al. (2004).

Logging with and without SMZs in 12 mixed hardwood forest catchments with highly erodible loess soils in Mississippi, USA was evaluated by (Keim and Schoenholtz 1999). Treatments consisted of: (1) unrestricted cable- and skidder-harvesting including the SMZ, (2) cable-yarding only harvesting in a SMZ of $30 \mathrm{~m}$ width and unrestricted cable- and skidder-harvesting of non-SMZ areas, (3) no-harvesting within a 30-m-wide SMZ and unrestricted cable- and skidder-harvesting of non-SMZ areas, and (4) no harvesting reference watershed. Streams in catchments without any SMZ protection had mean total suspended solids (TSS) concentrations 2.9, 3.2, and 1.8 times the concentration of the reference watershed stream with SMZs and no harvesting (mean TSS of 244.2, 272.0, 147.4, and $83.7 \mathrm{mg} \mathrm{L}^{-1}$ for treatments $1,2,3$, and 4, respectively). While this indicated the water quality protection value of SMZs, the responses of treatments 2 and 3 indicated the importance of minimizing soil disturbance within an SMZ. The results suggest that the SMZs did not function in trapping sediment originating in harvested areas outside the SMZ buffer. Instead, the reduced sediment input into streams was achieved by creating less soil disturbance within the SMZ. The authors concluded that SMZ prescriptions should focus on eliminating machine traffic within $10 \mathrm{~m}$ of streams.

\subsection{Objectives}

The previous section highlights the paucity of studies on soil erosion and in-stream turbidity in relation to tree harvesting in SMZs that separate the effects of harvesting per se from other potential contributing factors, e.g., roads, cattle, and upland harvesting. In the context of an agricultural landscape with SMZ plantations, a case study in Tasmania, Australia presented a rare opportunity to compare sediment contributions from cattle disturbance and a road with that from a tree harvesting operation in a SMZ with minimal mechanical disturbance or traffic. We did not examine other potential effects of the SMZ, e.g., other water quality parameters, biodiversity, etc.

\section{Materials and methods}

\subsection{Site description}

The research site is located on a farm in northwest Tasmania south of the town of Burnie (Fig. 3, longitude
145.7 E, latitude 41.2 S). The stream studied is an intermittent tributary of the upper part of the catchment of the Pet River, which is one of two perennial rivers supplying water to Burnie. The farm has a total area of 243 ha used $70 \%$ for beef cattle grazing, $9 \%$ for annual cropping, $13 \%$ for eucalypt and pine plantations, and the balance for roads, buildings, water bodies etc. The area of eucalypt plantations harvested during the study was 17 ha (Fig. 4). Soils are classified as red and brown Ferrosols ((Isbell 1996); Oxisols and Alfisols in the USA classification system) derived from Tertiary basalt bedrock with slopes $<5 \%$, and good structure. The Ferrosol soils found at the site are likely to be the most robust of soils in Tasmania and least likely to show water quality impacts following disturbance. They have very high aggregate stability, very high infiltration properties, very low erodibility, and low dispersibility. Eucalyptus nitens seedlings were planted in 1989 in a variable width SMZ (14 to $88 \mathrm{~m}$ either side of the stream channel) along the north-flowing tributary of the Pet River, a west-flowing subtributary, and at other locations on the farm. A few naturally regenerated blackwoods (Acacia melanoxylon) were the only other tree species that grew among the eucalypts. Understory vegetation was predominantly blackberry (Rubus fruticosus) and bracken fern (Pteridium aquilinim). The site has a cool, temperate climate, with a mean annual rainfall of c. $1541 \mathrm{~mm}$ (measured at Tewkesbury, $7 \mathrm{~km}$ west of the farm), a summer minimum rainfall of $70 \mathrm{~mm}$ per month in January and February, and a winter maximum rainfall of $213 \mathrm{~mm}$ in July.

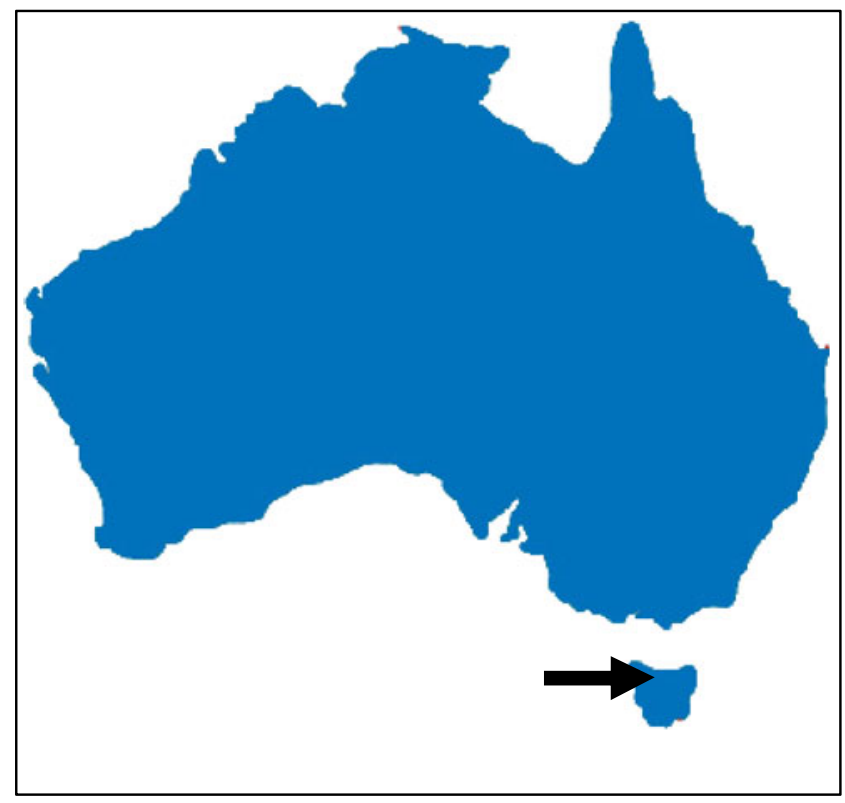

Fig. 3 Location of SMZ harvesting study south of Burnie, Tasmania, Australia (indicated by the arrow) 
Fig. 4 Harvested and nonharvested SMZ plantations in relation to streams and roads on the farm. Dams $(D)$ and stream $(S)$ sampling points are also indicated. Dashed lines are harvested stands. Uncut stands are marked by the shaded areas. The catchment boundary is marked by a dotted and dashed line. The tributary channels are the small solid lines

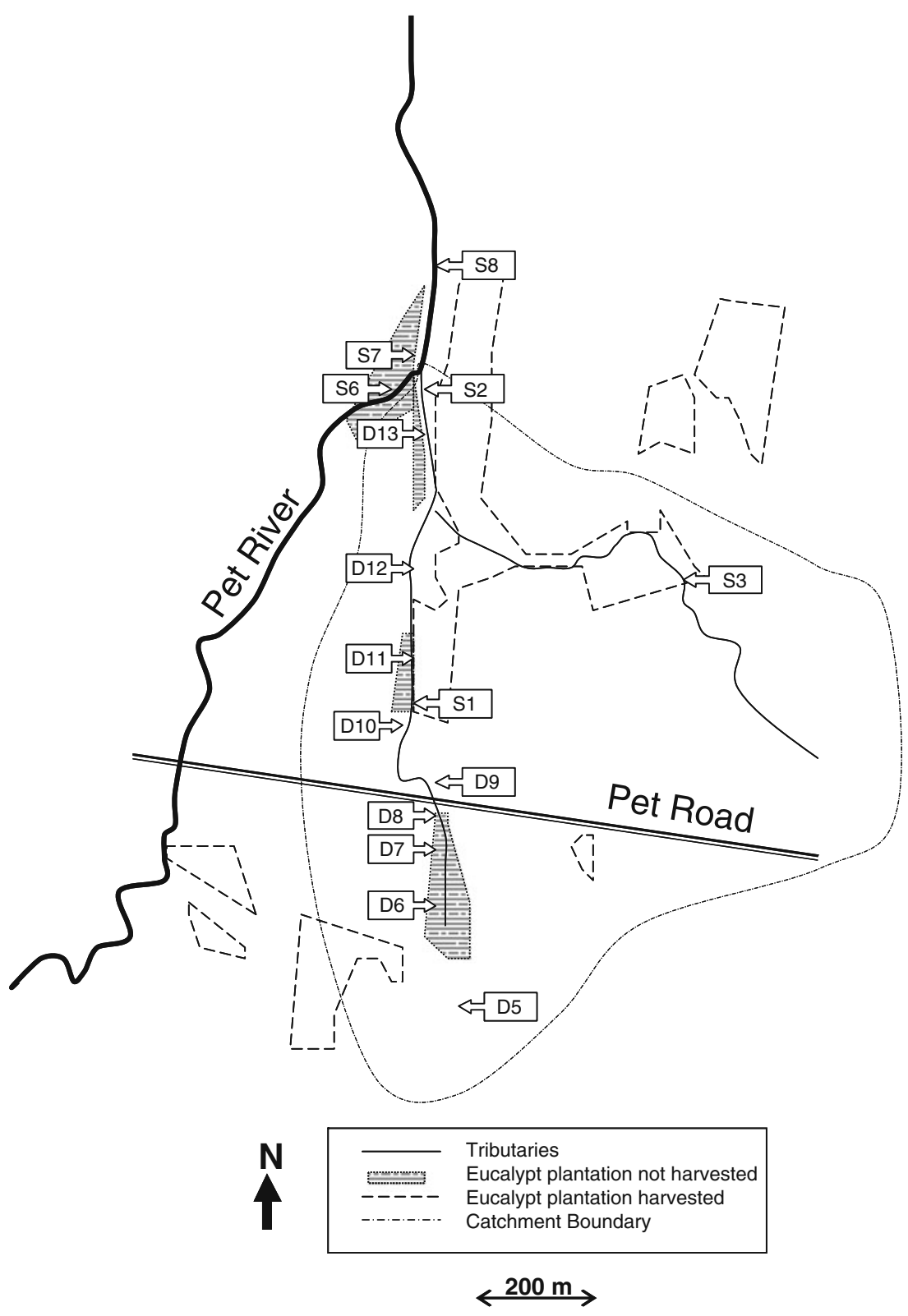

The study farm is a working beef cattle operation. Cattle had access to the SMZ and the Pet River tributary at selected points prior to the harvesting operation. For the most part, cattle were excluded from the tributary channel and dams from D10 to D13. There was more use of dams outside the SMZs for watering than those inside the SMZs. After harvesting, cattle access was greater due to the removal of fencing during the harvesting operation. Farm plans call for restoration of the SMZ fencing after site preparation and replanting. Plans for these two operations were in process but not finalized at the time this paper was prepared. Also, the uncut reference section at the head of the Pet River tributary had more cattle traffic due to animal concentration in the upper paddocks for sorting and shipping to market both pre- and postharvest.

\subsection{Harvesting}

Tree harvesting was carried out in accordance with the principles and approaches specified in the Tasmania Code of Forest Practices and included an approved harvesting plan (Forest Practices Board 2000). No road construction was required in the SMZ, and access was limited mainly to existing roads and paddock tracks. Tree stems were cut on the east side of the north-south SMZ on the main tributary north of Pet Road, and on all of the subtributary that flows west and perpendicular to the main tributary. Some areas of harvested plantation were in small blocks upslope of the SMZ (see Fig. 4). Stems were cut with hydraulic shears, delimbed, debarked, topped, and moved to landings by Tigercat 845C (ER Technology, Paris, Ontario, Canada) 
tracked harvesters (Fig. 5) and wheeled forwarders. Harvesting occurred during March and April 2009 while surface soil conditions were still dry. In May 2009, the landowner attempted to burn harvesting slash and forest floor material in preparation for planting of a second tree crop, but only one small area (maximum area c. $400 \mathrm{~m}^{2}$ ) could be burnt due to slash moisture conditions resulting from green wood and small amounts of rainfall.

\subsection{Sampling procedures}

\subsubsection{Sampling points}

A series of 13 dams (for stock watering and irrigation) are located along the main tributary and subtributary (see Fig. 4; only dams sampled are shown). These dams serve as coarse sediment traps and therefore can be considered as another BMP within the SMZ. Their function in retaining sediment was not evaluated independently. Water sampling points were established on the main tributary at dam (D) D5, D6, D7, D8, D10, stream sampling point (S) S1, D11, D12, D13, S2, $15 \mathrm{~m}$ above the confluence of the tributary with the Pet River (S6), $2 \mathrm{~m}$ below the confluence (S7), and on the Pet River at the bottom of the harvesting area (S8). Sample point S1 lies at the foot of Dam 10, just inside the harvested SMZ (see Fig. 4). Sample point S2 is located below Dam 13 and just downstream of the main harvested portion of the SMZ. Cattle have direct access to the water in dams D5-D8 but not the lower dams (D10-D13). Road runoff was evident above D10. Although there are farm roads below D10, there is no evidence of sediment-bearing runoff on the mostly grassed tracks.
Grab samples were collected from flowing or still waters, depending on flow conditions. Grab samples were collected from the surface of the pooled water above each dam at the center point. Water samples collected at various depths in the dam pools indicated that the first meter of the water column had fairly uniform turbidities (data not presented). Each dam was equipped with an overflow culvert or spillway.

In 2009, until April, there was only a minor flow between dams resulting from seepage through dam walls. By May, there was a continual flow from D6 and lower in the main tributary, at $\mathrm{S} 3$, and lower in the subtributary. The Pet River flowed continuously during the study.

\subsubsection{Ground cover and tree size}

Percent cover was assessed on 15 line transects, 4 in the upper uncut SMZ and 11 in the harvested sections (Elzinga et al. 2009). The transects ranged in length from 20 to $87 \mathrm{~m}$ through the SMZ from paddock edge to stream or pond margin. All 15 transects were measured in early March 2009, prior to harvesting. In May 2009, the 11 transects in the harvested portion of the SMZ were remeasured after completion of tree harvesting and $\log$ removal. Line intercept distances were measured by surface type: vegetation, litter, coarse woody debris, soil, or rock. All transects were photo documented during the initial cover survey, but only the harvested areas were rephotographed in May 2009.

\subsubsection{Rainfall, turbidity, temperature, and water depth}

Water quality assessment of grab samples from the Pet River tributary was initiated in December 2008, at S1 and S2 when
Fig. 5 Tigercat tracked harvester delimbing and topping a felled E. nitens stem during the SMZ harvesting study. Note the slash coverage remaining in the harvested area (photo by Daniel G. Neary)

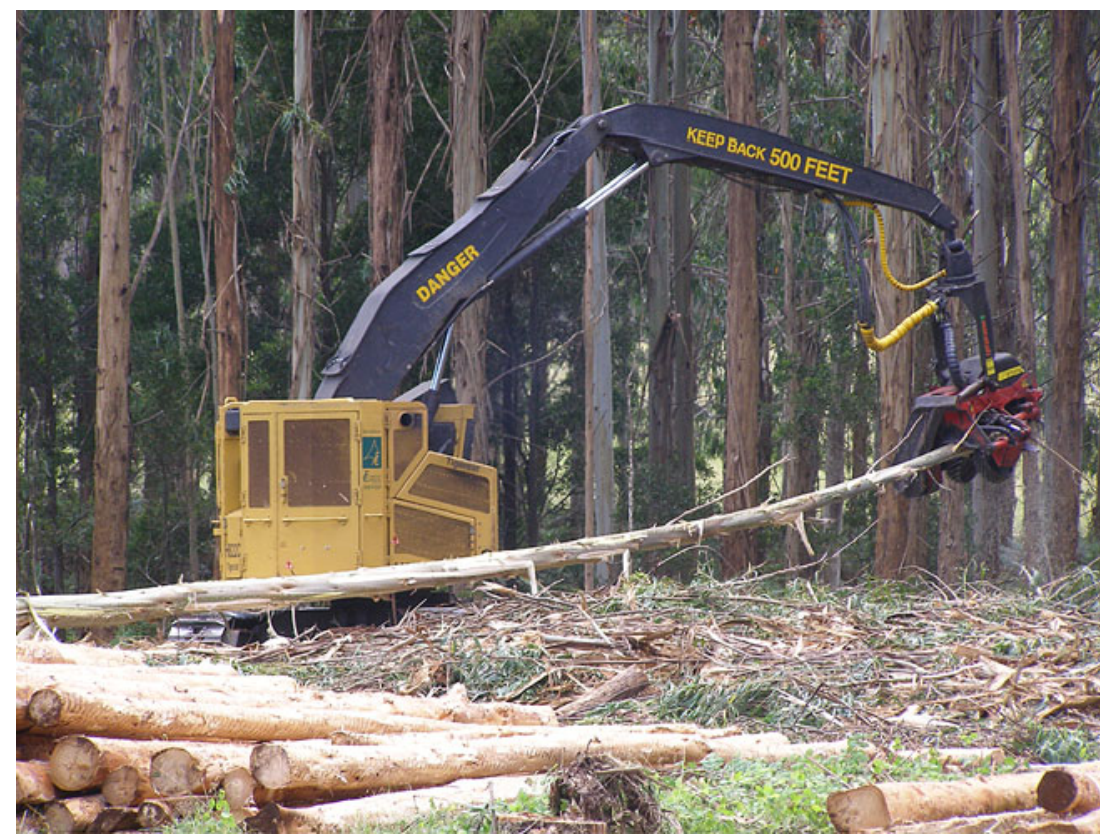


flowing, and conducted 0.5- to 2-monthly to cover a range of flow levels pre- and postharvesting. Single grab samples were collected in plastic containers by hand at each designated sampling point that had flowing water without disturbing bottom sediments. Grab sampling was extended to other sampling points on the main tributary in early March 2009 (preharvest), and repeated in late May (postharvest). Turbidity of grab samples was measured using a portable meter calibrated for the range $0.1-1,000$ NTUs. Water containing $1 \mathrm{mg} \mathrm{L}^{-1}$ of finely divided silica usually has a turbidity of 1 NTU. A silica concentration to NTU level was developed for this site but is not used in this paper since only turbidity values are discussed (Sims and Cotching 2000). To monitor water quality and flow trends postharvest, automated water quality measurement instruments were installed in late May 2009 at D10 (turbidity), S1 (water level), D13 (turbidity), and S2 (water level). Water levels were monitored every minute and averaged over 15-min intervals using Odyssey ${ }^{\mathbb{B}}$ capacitance probes, each with a built-in datalogger. The Odyssey capacitance probe has a range of 0 to $1.5 \mathrm{~m}$ with a resolution of $1.5 \mathrm{~mm}$. The temperature sensor resolution is $0.02^{\circ} \mathrm{C}$. Depth by head pressure was determined and logged every minute, and averaged for $15 \mathrm{~min}$, hourly and daily time steps. Water levels were recorded to give an idea of relative water depths behind each dam. The overflow culverts and spillways did not provide adequate control sections to rate flow volumes.

Turbidity was automatically measured every $15 \mathrm{~min}$ using Environmental Systems and Services $2600^{\circledR}$ turbidity probes (0-2,000 NTU range) connected to Campbell Scientific ${ }^{\circledR}$ CR1000 dataloggers. The Campbell CR1000 Datalogger has a 2-GB memory expansion. It is powered by $1 \times$ BP 10 -W solar panel supported by $50 \mathrm{AH}$ deep cycle battery via a 4.5A solar regulator (Morningstar Corporation). Water temperature and electrical conductivity were measured using an Environmental Services and Systems CS-547A. Data were recorded every minute, and an average was logged on $15 \mathrm{~min}$, hourly and daily basis. The 2600 turbidity probe is an optical backscatter type with a range of 0 to 2,000 NTU. The zero and full-scale setting are $\pm 0.05 \%$ of the full-scale setting. Accuracy is $\pm 2 \%$ of the full scale. Response time is $2 \mathrm{~s}$ to full accuracy. The resolution is $10-15 \mathrm{~V}$ at $500 \mathrm{~mA}$ per reading. Output is on an analog 4-20 mA current loop. The probe has secondary surge protection ( $0.6 \mathrm{~J}$ of energy absorption). Also connected to the unit at D10 only was a Campbell Scientific ${ }^{\circledR}$ tipping bucket rain gage $(0.02 \mathrm{~mm}$ resolution).

\section{Results and discussion}

\subsection{Study limitations}

It should be recognized that there are limitations to this study. These include the intermittent nature of the Pet River tributary monitored in this study, the presence of dams along the tributary which may or may not be present in other locations, and the presence of one main road and several farm roads within the tributary catchment. However, the preliminary results of the study are useful since no other equivalent data sets are available in Tasmania or elsewhere in Australia. Storm flow data can be "hit or miss" depending on the stochastic nature of precipitation events. Virtually, every subcatchment in the Pet River catchment contains roads and cattle or other farming operations. Thus, that source of experimental variation cannot be factored out by catchment selection. This region contains extensive agroforestry operations and is the type of landscape that we are most interested in. Turbidity measured in the Pet River tributary in this study included only the fine silts and clays that remained in suspension after the coarser sediments settled primarily in Dam 10. The deposited coarse sediment was observed but not measured.

\subsection{SMZ cover}

The SMZ plantation had a stocking at planting of 794 trees per hectares, with $3.7 \mathrm{~m}$ between rows. At harvest, the stocking was 703 trees per hectares (89\% survival), the average tree diameter over bark at $1.3 \mathrm{~m}$ height was $33.0 \mathrm{~cm}(n=249)$, and the average tree height was $34.4 \mathrm{~m}$ $(n=6)$. Although of lower stocking, this plantation was similar in appearance and other metrics to industrial plantations in the region grown with the same species and silvicultural prescriptions.

Before harvesting, SMZ cover was dominated by vegetation and litter (Fig. 6). Vegetation and litter in the reference SMZ stand (transects 4-7) had mean cover percentages of $48.0 \%$ and $51.7 \%$, respectively. The cut portion of the SMZ had similar vegetation and litter covers (53.9\% and $43.7 \%$, respectively). After the harvest operation, vegetation and litter cover means dropped to $12.0 \%$ and $28.4 \%$, respectively. However, slash cover increased from $0.0 \%$ to $49.2 \%$ with the logging. Vegetation cover on the measurement transects, mostly blackberry and bracken fern, ranged from $25.0 \%$ to $94.8 \%$. Litter and slash accounted for $5.2 \%$ to $88.6 \%$. Bare soil was found on only $33 \%$ of the transects, with the maximum cover being $1.3 \%$. Rocks made up $1.2 \%$ of the area in one transect.

Soil exposure prior to harvesting is compared to that measured after cutting in Fig. 7. Mean bare soil cover was $0.0 \%$ and $0.5 \%$ in the reference and harvest stands, respectively, prior to the tree harvest. Soil exposed by the harvesting operation increased to a mean of $10 \%$. One transect had $22.6 \%$ bare soil, but most transects were $<13 \%$ bare soil. Transect 3 had the highest percentage of bare soil (22.6\%), but this transect ran across a log deck where there had been a lot of machinery traffic. Slope at this location 
Fig. 6 Coverage of litter and vegetation in SMZ transects in March 2009 prior to harvesting

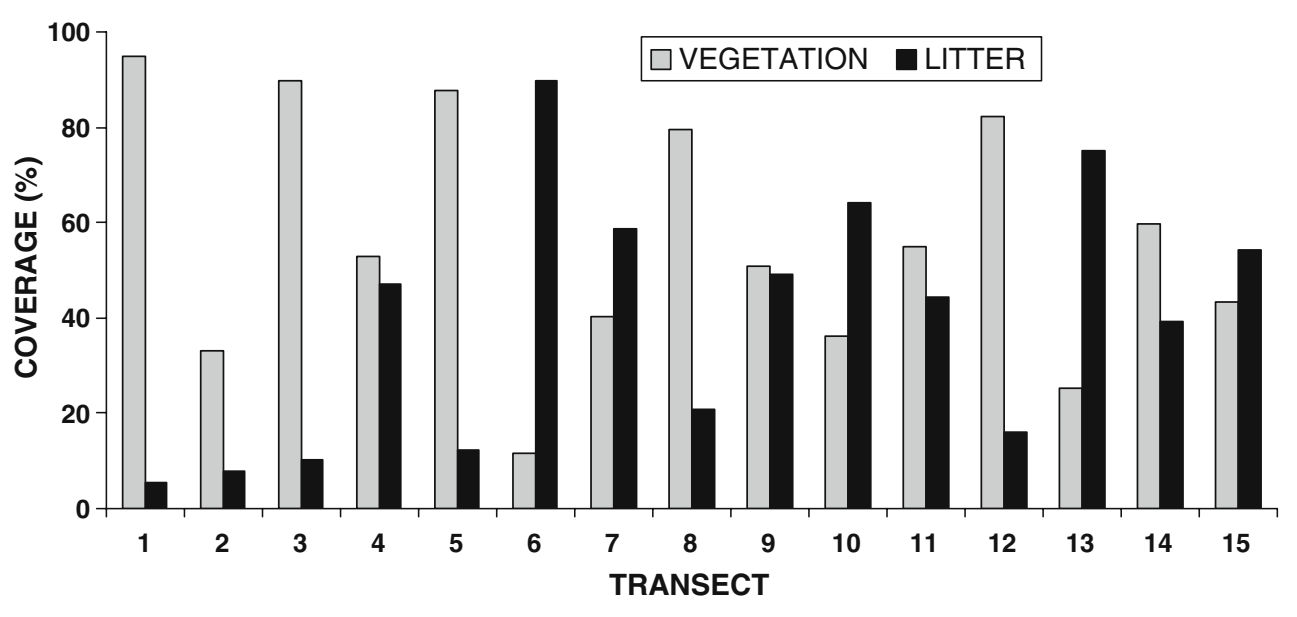

was $0 \%$, so the erosion hazard was very low. In the $10-\mathrm{m}$ MEZ, only three transects had any bare soil (transects 1,3 , and 15). Percent bare soil in these three transects was $20 \%$, $1 \%$, and $11 \%$, respectively. The high percent exposed soil in Transect 1 was due to burning of logging slash and not to machinery traffic.

On the whole, the area of soil exposure by tree harvesting was very small. There was also no evidence of sediment movement on portions of the cover transects that contained bare soil. Runoff pathways in these Ferrosol soils are normally quite short due to high infiltration rates. There was no visible evidence in May 2009 of sediment generation or trapping in the SMZ, because the cover conditions precluded erosion from occurring to any measurable extent. The expected outcome of this result was low or no effect on stream turbidity. The logging operation was conducted using BMPs, which retained a good coverage of slash on the ground. Tracked harvesters that produced minimal ground disturbance in most of the SMZ were able to extract trees from the 10-m streamside MEZ without turning or disturbing the soil unduly. Rainfall during the March-May period after harvesting was insufficient to induce any noticeable erosion.

\subsection{Turbidity}

Turbidity in a series of dams along the main tributary was documented by grab sampling prior to logging in March 2009 and postharvest in May (Fig. 8). These series were augmented by grab samples at S1, S2, and S6 (Pet River above the confluence with the study tributary) on seven occasions preharvest and on ten occasions postharvest (Table 2). Automated sampling with turbidity probes began in late May 2009.
Fig. 7 Bare soil coverage in transects pre- and postharvest averaged for each total transect, and for the last $10 \mathrm{~m}$ closest to the water's edge

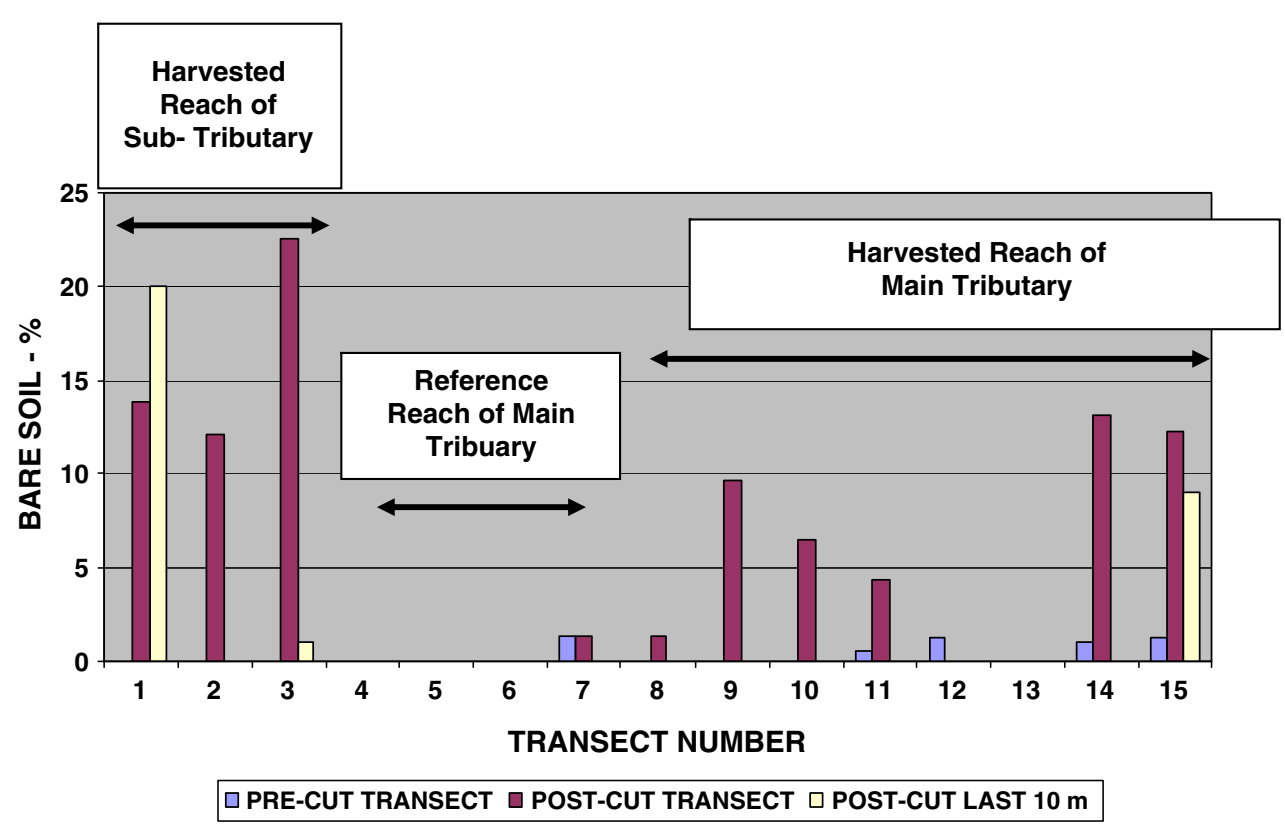


Fig. 8 Turbidity from single grab samples longitudinally downstream (D5 to S8) along the main tributary and part of the Pet River preharvest (March 2009) and postharvest (May 2009)

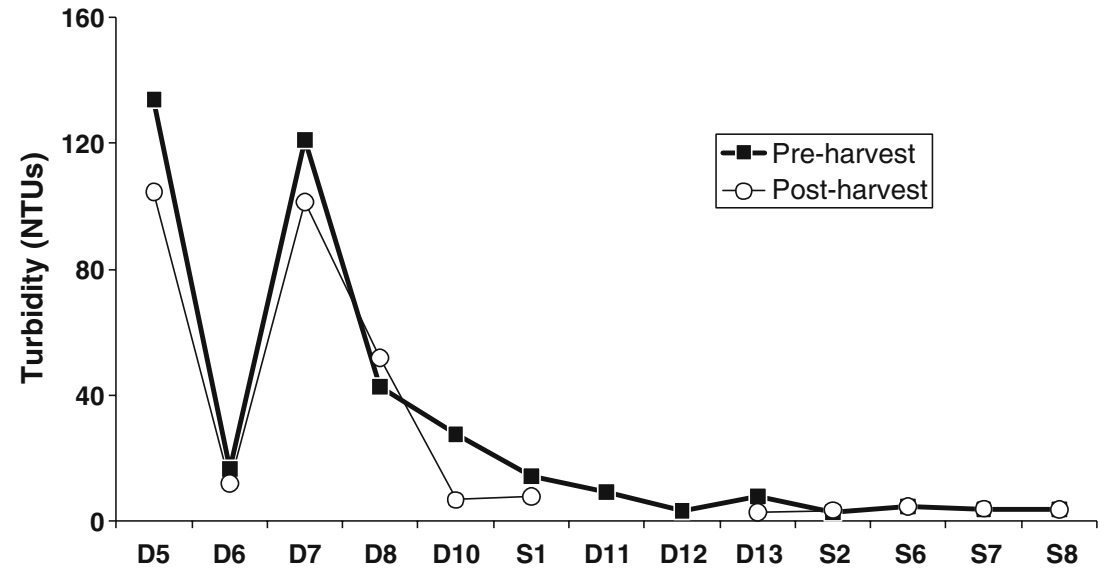

\subsubsection{Cattle impacts}

While cattle impacts on water quality were not an objective of this research, the data do clearly demonstrate animal effects at D5 and D7, above which there were no roads or farm tracks (see Fig. 8). All the subcatchments in the Pet River watershed are affected by cattle since this is an agricultural landscape. Animal traffic in riparian areas is recognized as a significant source of sediment input into streams in surface runoff (Clary and Kruse 2004). Dam 5 is above the reference forested SMZ in an open paddock and is a stock-watering pond susceptible to animal traffic (see Fig. 4). On both occasions in the longitudinal sampling (see Fig. 8), it had the highest turbidities (133.8 and 121 NTUs). Sample points D6, D7, and D8 are dams within the upper unharvested reference SMZ and are periodically accessible to cattle. The livestock frequented D7 and D8 during the study, which explains the higher turbidities there compared to the samples from D6 where there was no visible stock activity. Turbidities attenuated downstream of the cattle activity area due to the lack of additional disturbance from animal traffic and filtering, settling, and detention properties of dams D10-D13.
Table 2 Turbidity in grab samples at $\mathrm{S} 1$ (above harvest reach), S2 (below harvest reach) pre- and postharvest, and S6 (Pet River reference above the confluence with the study tributary)

\begin{tabular}{|c|c|c|c|c|c|}
\hline \multirow[t]{2}{*}{ Sampling date (day/month/year) } & \multicolumn{2}{|l|}{ Rainfall } & \multicolumn{3}{|c|}{ Turbidity } \\
\hline & $\begin{array}{l}\text { Antecedent } \\
\mathrm{mm}\end{array}$ & $\begin{array}{l}\text { Previous 5days } \\
\mathrm{mm}\end{array}$ & $\begin{array}{l}\text { S1 } \\
\text { NTUs }\end{array}$ & $\begin{array}{l}\text { S2 } \\
\text { NTUs }\end{array}$ & $\begin{array}{l}\text { S6 } \\
\text { NTUs }\end{array}$ \\
\hline \multicolumn{6}{|l|}{ Preharvest } \\
\hline 01/12/09 & 144.1 & 20.8 & 5.3 & 1.5 & - \\
\hline $17 / 12 / 09$ & 80.0 & 13.3 & 2.8 & 1.1 & - \\
\hline 08/01/09 & 74.1 & 3.8 & 1.3 & 1.4 & - \\
\hline $19 / 01 / 09$ & 15.2 & 11.5 & 52.4 & 1.4 & - \\
\hline $26 / 02 / 09$ & 68.5 & 7.1 & 15.7 & 5.2 & - \\
\hline 03/03/09 & 0.2 & 0.2 & 7.1 & 3.1 & - \\
\hline $17 / 04 / 09$ & 181.3 & 32.4 & 64.6 & 2.2 & 3.5 \\
\hline \multicolumn{6}{|l|}{ Postharvest } \\
\hline $25 / 06 / 09$ & 224.9 & 47.6 & 5.8 & 6.8 & 3.8 \\
\hline 02/07/09 & 199.6 & 74.8 & 4.6 & 3.1 & 6.6 \\
\hline $30 / 07 / 09$ & 320.9 & 72.5 & 4.3 & 1.6 & 2.3 \\
\hline $26 / 08 / 09$ & 319.4 & 104.4 & 45.6 & 17.6 & 18.8 \\
\hline 29/09/09 & 322.4 & 61.4 & 2.8 & 8.3 & 1.2 \\
\hline 08/10/09 & 13.9 & 8.0 & 7.1 & 3.4 & 3.3 \\
\hline $26 / 10 / 09$ & 39.0 & 0.7 & 7.2 & 6.3 & 4.4 \\
\hline $30 / 11 / 09$ & 91.0 & 37.8 & 14.3 & 8.6 & 5.6 \\
\hline $04 / 01 / 10$ & 57.5 & 3.3 & 11.0 & 2.9 & 4.8 \\
\hline $28 / 01 / 10$ & 13.8 & 0.0 & 86.2 & 2.4 & 4.6 \\
\hline
\end{tabular}




\subsubsection{Road effects}

Like cattle impacts on water quality, road effects were not part of the original study design or objectives of the study. Instrumentation was not put into place to separate out road effects. However, their presence and impacts need to be recognized since highways, side roads, and farm tracks are pervasive throughout the Pet River catchment. Roads have been recognized as major contributors of sediment into streams of both forested and agricultural catchments (Beschta 1978; Swift 1986; Ziemer and Ryan 2000). The Pet Road is a case in point since it cuts across the upper third of the study tributary. Sediment movement off of this road and into the tributary is readily visible in ditch deposits and scour as well as coarse sediment deposits in D10. The turbidities shown in Fig. 8 do not show any road impacts on water quality since both samplings were done during dry periods. The continuous sampling that captured the turbidity spikes from the storm of 30 June to 1 July (Fig. 9) cannot separate out the relative contributions of roads and cattle activity. It is possible that the turbidity spikes in the 320 to 360 NTU range were due to sediment in road runoff, either delivered from the road during the event or delivered during previous events over many years, that settled in D10 and was resuspended during the event.
What is important to note is that these pulses of turbid water did not carry on far below D10 and were not measurable at D13, despite continuous stream flow through the tributary system at the time (see Fig. 9). The lack of large turbidity spikes downstream of D10 indicates that the turbidity effect from tree harvesting in the SMZ was absent or minor compared to the cattle and road effects, and that the BMPs were effective.

\subsubsection{Tree harvesting effects}

Sample D10 is in the dam immediately above the forested SMZ that was harvested on the eastern side (see Fig. 4). Sample point S1 is in the drainage below D10. The next series of dams (D11 through D13) are also located in the main tributary. Sample point S2 is below D13 and c. $15 \mathrm{~m}$ above the confluence of the tributary with the Pet River. Its turbidity levels on both occasions shown in Fig. 8 were the same as those in the Pet River above (SP6) and below (SP7) the confluence with the tributary ( $<3$ NTUs). Both of these samplings occurred during dry periods, not storm events.

The main tributary had only minimal seepage flow in the S1 to S2 reach during the March sampling. As indicated, comparison of the grab sample data from the March and
Fig. 9 Rainfallin millimeter on the Pet River tributary catchment during the 2009 winter rainy period, and continuous turbidity measurements at D10 and D13 in 15-min intervals from 27 May 2005 to 9 October 2009. $y$-axis units for Dams 10 and 13 are in NTUs on a log scale

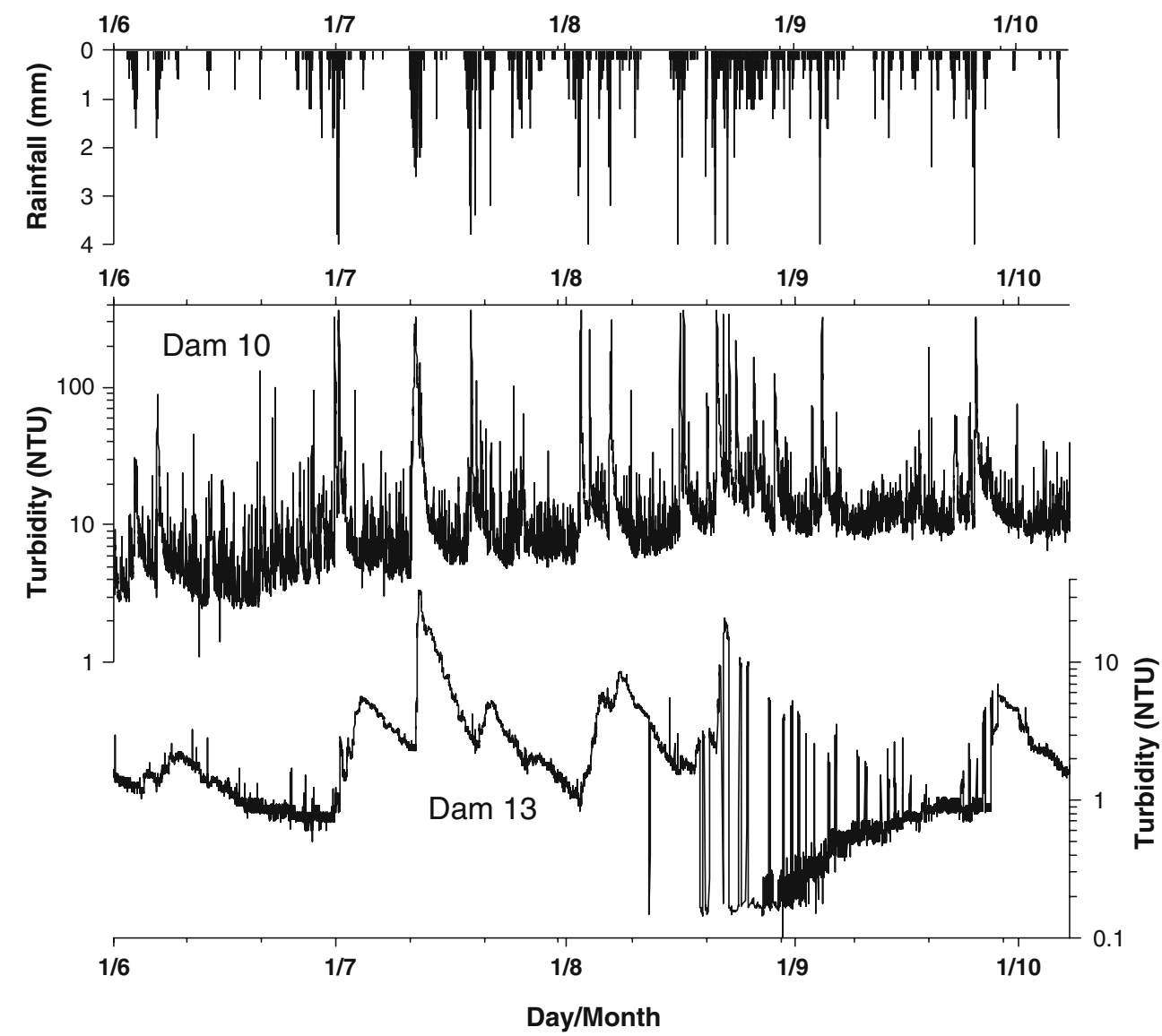


May longitudinal series (see Fig. 8), and later grab samples (see Table 2), showed that there was no effect of tree harvesting in the SMZ on water quality as measured by turbidity at these dam and stream sampling points. Grab samples from S1, S2, and S6 collected between January 2009 and January 2010 indicated that turbidities were elevated only at S1 where there was influence from cattleand road-derived sediments. Water turbidities at S2, below D13, were within the range of samples for the Pet River above the confluence of the monitored tributary (see Table 2). On five dates, postharvest water samples collected at S2 (see Table 2) were equal to or less than the turbidity of the reference stream (S6) that had only one small area logged adjacent to the channel (see Fig. 4). The highest turbidities detected in grab samples at S2 and S6 on 26 August were the only ones above 10 NTUs and were associated with the highest antecedent rainfalls (see Table 2). The other higher turbidity values measured by grab sampling at $\mathrm{S} 2$ were also associated with higher rain amounts (37.8 to $61.4 \mathrm{~mm}$ in 5 days). These values were only "high" in reference to S2 and S6 data, not S1 where turbidity levels were consistently higher.

Automated water quality sensors installed in May 2009 allowed for the determination of stormflow-related differences in turbidity caused by tree harvesting and associated rainfall. There were nearly 50 rainfall events during the winter rainy period of 2009 when amounts exceeded $1 \mathrm{~mm}$ in 15 min (see Fig. 9). Eight of these rainfalls reached or exceeded $4 \mathrm{~mm}$ in $15 \mathrm{~min}$. While there were not any excessively large precipitation events, the number of time periods with continuous rainfall potentially set up wetted conditions that would allow erosion due to surface runoff (McDowell and Sharpley 2002).

The peak rainfall of 2009 occurred on 25 September 2009 when the 15 -min precipitation rate was $5.6 \mathrm{~mm}$ $\left(22.4 \mathrm{~mm} \mathrm{~h}^{-1}\right)$. Turbidities peaked at 300 and 8 NTUs in that storm event for D10 and D13, respectively. But this did not coincide with the peak turbidity at D10 (see Fig. 9). Of the 20+ high turbidities in the 300-362 NTUs range, the peak turbidity in D10 was 362.4 NTUs at 0115 h on 3 August 2009, nearly 2 months earlier. At the same time, the turbidity value in D13 overflow was 0.92 NTUs. Rainfall was around $3.3 \mathrm{~mm}$ for the $15-\mathrm{min}$ duration, but was also part of a longer duration storm coming after a rainy period that started in mid-July. The peak turbidity at D13 was 33.6 NTUs at 1030 h on 12 July 2009 , an order of magnitude coincident with and of similar magnitude to that at D10, indicating that some other source of sediment came into play, probably from stream connectivity from D10 to D13. The turbidity recession curve at D13 from the 12 July storm was similar to those of four other events in July, August, and September (see Fig. 9). Antecedent rainfall during those events was higher with grab sample to grab sample amounts of 200 to $322 \mathrm{~mm}$, and 5-day presampling amounts of 61 to $104 \mathrm{~mm}$. For much of the time period sampled by the automated equipment, the turbidity at D13 was $<5$ NTUs, a value comparable to the Pet River above its confluence with the SMZ study tributary (see S6 in Table 2).

For many of the storm events, there was a time lag of 3 to 5 days between peak turbidity at D10 and D13 due to the time needed for water to flow from D10 through D11 and D12 to D13. Stream and dam turbidities throughout the study were influenced by road runoff and flow from upstream dams that had high levels of farm animal traffic. Peak turbidity at D13 was consistently one to two orders of magnitude lower than at D10 during these storms. The peak dampening effect was a combination of a streamflow dilution effect between D10 and D13, effective sediment movement detention by surface roughness on the harvested sites, and a good indication of an overall lower level of sediment entrainment in surface runoff from the tree harvesting area due to effective logging operation BMPs.

Continuous turbidity and rainfall data at D10 during a series of discrete rainfall events within one storm from 30 June through 1 July 2009 indicate that turbidities spiked to over 300 NTUs three times during the event (Fig. 10). This spike was in response to rainfall of 1.5 to $4.0 \mathrm{~mm}$ in $15-\mathrm{min}$ periods (6 to $16 \mathrm{~mm} \mathrm{~h}^{-1}$ ), while turbidity at D13 remained $<2.5$ NTUs. At D10, there was sediment input from the Pet Road and from an adjacent paddock that was cultivated to establish livestock fodder (see Fig. 4). Turbid runoff from the Pet Road has been observed entering the main tributary during earlier storm events. It was speculated at the time that road runoff was probably the most significant contributor of both total suspended sediment and bedload to the main tributary above D10. There were observations at the start of the study that D10 had noticeable accumulations of coarse sediment. It is evident that during the 30 June to 1 July storm event that SMZ harvesting did not affect water quality since turbidities remained below 2.5 NTUs at D13 for the entire time period of the storm (Fig. 11). Turbidity data for D13 were collected continuously from installation of the automated stations in May through to the monitored storm event in early July 2009. There were several transient spikes in turbidity during the monitoring period with one reaching just over 40 NTUs on 17 June 2009, but these were most likely artifacts resulting from leaf material, insects, or other floating detritus since there was no pattern of increasing turbidity followed by a gradual return to base levels as seen in Fig. 9. Hence, the harvesting BMPs in the SMZ appear to have been effective in maintaining low turbidities.

The dam system in the intermittent tributaries comprises another BMP practice that is effective in trapping road-, 
Fig. 10 Rainfall (broken line) and turbidity (solid line) at Dam 10 during the 30 June to 1 July 2009 storm

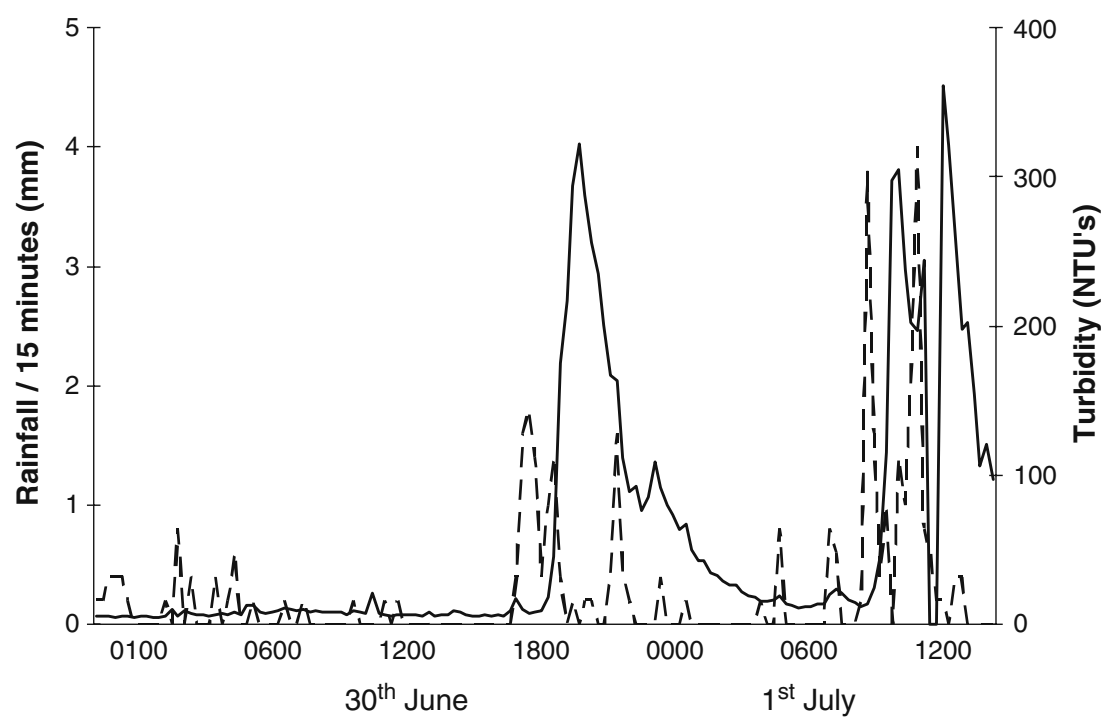

\subsection{Management implications}

The data generated in this case study indicate that the use of harvesting BMPs such as tracked fellers and skidders, machinery exclusion zones next to stream channels, and minimal harvesting road construction can be effective at minimizing sediment delivery to streams. This case study demonstrated that road-derived sediment can be trapped by in-stream dams. However, the lack of any turbidity "spikes" in the lower of two sampling sites along the Pet River tributary (D13 and S2) indicated that there was not a significant amount of sediment delivery to streams within the SMZ. Trees in the SMZs were harvested from S1 all the way to S2 (and lower), but S2 turbidities stayed at background levels. In the absence of the four dams above S2, a sediment "signal" from the Pet River Road might have been discernable at S2. Water flow was continuous from Dam 10 to Dam 13, so any significant harvestingrelated turbidity would have been detected without dams.
Fig. 11 Turbidity at Dam 13 turbidity 27 May to 1 July 2009. The storm period of 30 June to 1 July shown in Fig. 10 is in the circled segment

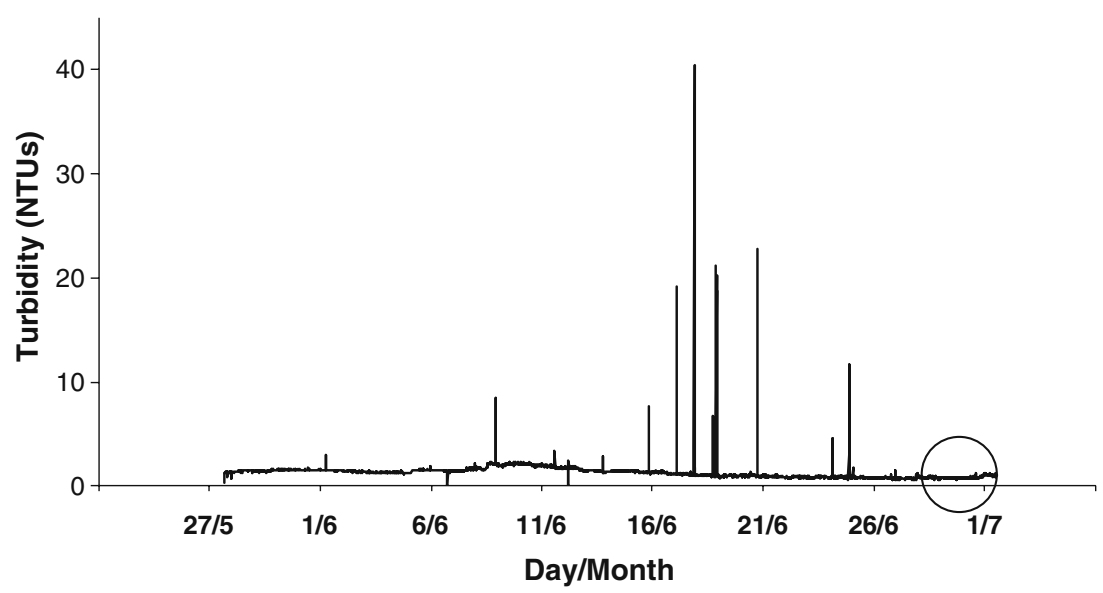


Certainly, the dams add an extra level of protection for stream water quality. However, the overriding results of the monitoring to date indicate that the harvesting BMPs were effective in maintaining water quality under these low slopes and low erodibility conditions, i.e., trees in SMZs were harvested using existing BMPs without compromising water quality.

\subsection{Research needs}

This case study clearly points out a number of areas where future research could be useful. Any future research will also probably rely on "case study" scenarios, since there is little likelihood of establishing a study with tightly controlled treatments in an operational agroforestry landscape, and then waiting one or two decades for trees to grow to a size where they can be harvested. As opportunities present themselves, some of the aspects of SMZ harvesting that require future research include:

- SMZ harvesting where catchments do not have instream dams

- Evaluation of other harvesting BMPs

- Comparison of thinning versus clear-felled harvesting scenarios

- Comparison of grass versus tree vegetation for protection of water quality

- Comparison of water quality protection provided by SMZs and harvesting BMPs across a range of slopes, soil erodibility, and precipitation amounts and intensities

- Responses of poorly drained soils to SMZ logging

- Comparison of catchment water quality in perennial and intermittent streams after SMZ logging

- Evaluation of cattle impacts on water quality compared to tree harvesting

\section{Conclusions and recommendations}

The literature review and case study clearly indicate that SMZs can be very effective in detaining runoff sediment when combined with harvesting BMPs. In this study, there was no visible evidence of erosion in the harvested portion of the SMZ. Turbidity levels were elevated in the study tributary above the SMZ tree cutting zone due to erosion and/or in-stream resuspension of sediment associated with cattle access to dams and runoff from the Pet Road. Turbidity levels declined substantially from Dam 10 at the upper part of the cutting area to Dam 13 at the lower end. Water turbidities in Dam 13 and overflow during the winter flow period were within the range of the Pet River above the confluence with the SMZ harvest tributary (1.2 to 18.8 NTUs). This is a clear indication that disturbance in the
SMZ harvest zone did not contribute to decreased water quality as indicated by turbidity levels in the tributary streamflow. Use of tracked harvesters, a MEZ, and retention of slash on-site were instrumental in reducing soil disturbance and potential erosion. Both the cover and stream turbidity data indicate that trees can be harvested within the 10-m streamside zone and up to the steam edge without compromising water quality values of the SMZ. This study and those reviewed in the literature indicate that permanent roads, temporary haul roads, and skid tracks can be major generators of sediment inputs to streams. Separate tree and grass or tree-grass combinations in SMZs could be established in agroforestry landscapes to provide water quality and other functions. Harvesting down to stream and lake edges can be accomplished using logging BMPs without degrading water quality. However, these results may not apply on all sites and situations.

Continued evaluation of SMZ tree cutting and harvesting BMPs in different configurations and sites over longer periods of time should be conducted to improve the SMZ effectiveness database in agroforestry landscapes and to improve our understanding of the impacts of SMZ tree harvesting. These research needs are itemized in Section 3.5 above. Cattle impacts on stream bank stability and stream water quality in Australia in particular need to be evaluated as suggested by Zaimes et al. (2004) and Marlow et al. (1987).

Acknowledgments This research was conducted while the senior author was a visitor to CSIRO Australia and supported by a Sir Frederick McMaster research fellowship. We also thank the Cooperative Research Center for Forestry and the Landscape Logic Commonwealth Environmental Research Facility Hub for support in developing this paper, and Richard Boland for access to his property to conduct the field study. Nico Marcar, Gary Sheridan, and Sadanandan Nambiar provided valuable comments on an earlier draft.

Open Access This article is distributed under the terms of the Creative Commons Attribution Noncommercial License which permits any noncommercial use, distribution, and reproduction in any medium, provided the original author(s) and source are credited.

\section{References}

Arthur MA, Coltharp GB, Brown DL (1998) Effects of best management practices on forest streamwater quality in eastern Kentucky. J Am Water Res Assoc 34:481-495

Baker MB Jr, Ffolliott PF, DeBano LF, Neary DG (eds) (2003) Hydrology, ecology, and management of riparian areas in the southwestern United States. Lewis Publ, Boca Raton

Beasley RS (1979) Intensive site preparation and sediment loss on steep watersheds in the Gulf Coastal Plain. Soil Sci Soc Am J 43:412-417

Beasley RS, Granillo AB (1988) Sediment and water yields from managed forests on flat coastal plain sites. Water Res Bull 24:361-366

Beschta RL (1978) Long-term patterns of sediment production following road construction and logging in the Oregon Coast Range. Water Resour Res 14(6):1011-1016 
Binkley D, Brown TC (1993) Forest practices as nonpoint sources of pollution in North America. Water Res Bull 29:729-740

BRS (2009a) Land use in Australia - at a glance. Bureau of Rural Sciences. Available at: http://adl.brs.gov.au/mapserv/landuse/ pdf_files/Web_LandataGlance.pdf. Accessed 21 August 2009

BRS (2009b) Australia's plantations 2009 Inventory Update. Bur Rural Sci. Available at: http://adl.brs.gov.au/mapserv/plant/ NPI2009Update.pdf. Accessed 21 August 2009

Clary WP, Kruse WH (2004) Chapter 11: livestock grazing in riparian areas: environmental impacts, management, practices and management implications. In: Baker MB Jr, Ffolliott PF, DeBano LF, Neary DG (eds) Riparian areas of the southwestern United States. Lewis Publishers, Boca Raton, pp 237-258

Collier KJ, Rutherford JC, Quinn JM, Davies-Colley RJ (2001) Forecasting rehabilitation outcomes for degraded New Zealand pastoral streams. Wat Sci Technol 43:175-184

Comerford NB, Neary DG, Mansell RS (1992) The effectiveness of buffer strips for ameliorating offsite transport of sediment, nutrients, and pesticides from silvicultural operations. National Council of the Paper Industry for Air and Stream Improvement Tech Bull 631, New York

Cooper JR, Gilliam JW, Daniels RB, Robarge WP (1987) Riparian areas as filters for agricultural sediment. Soil Sci Soc Am J 51:416-420

Correll DL (2005) Principles of planning and establishment of buffer zones. Ecol Eng 24:433-439

Cowardin LM, Golet FC (1995) US Fish and Wildlife Service 1979 wetland classification: a review. Plant Ecol 118:139-152

Cowardin LM, Carter V, Golet FC, LaRoe ET (1979) Classification of wetlands and deepwater habitats of the United States. FWS/OBS79/31. US Dept Interior Fish Wildlife Serv Washington DC

Davies PE, Nelson M (1994) Relationships between riparian buffer widths and the effects of logging on stream habitat, invertebrate community composition and fish abundance. Aust J Mar Freshw Res 45:1289-1305

DeBano LF, Neary DG, Ffolliott PF (2005) Chapter 2: effects on soil physical properties. In: Neary DG, Ryan KC, DeBano LF (eds) Fire effects on soil and water. USDA For Serv Rocky Mtn Res Stn Gen Tech Rep RMRS-GTR-42, Volume 4: Fort Collins, pp 29-52

Dosskey MG (2001) Toward quantifying water pollution abatement in response to installing buffers on crop land. Environ Manage 28:577-598

DSE (2008) Green Paper: Opportunities in carbon sequestration. Victorian Government Department of Sustainability and Environment, Melbourne, Victoria, 4 p. Available at: http://dse.vic. gov.au/DSE. Accessed 06 July 2009

Elzinga CL, Salzer DW, Willoughby JW, Gibbs JP (2009) Monitoring plant and animal populations. Wiley-Blackwell, Hoboken

Ensign SH, Mallin MA (2001) Stream water quality changes following timber harvest in a coastal plain swamp forest. Water Res 35:3381-3390

FAO (2008) Soaring food prices: facts, perspectives, impacts and actions required In: Proceedings of "High-Level Conference on World Food Security: The Challenges of Climate Change and Bioenergy", Rome, 3-5 June 2008, FAO HLC/08/INF/1

Ffolliott PF, DeBano LF, Baker MB Jr, Neary DG, Brooks KN (2003) Chapter 4: hydrology and impacts of disturbances on hydrologic functioning. In: Baker MB Jr, Ffolliott PF, DeBano LF, Neary DG (eds) Hydrology, ecology and management of riparian areas in the southwestern United States. Lewis Publ, Boca Raton

Fiener P, Auerswald K (2003) Effectiveness of grassed waterways in reducing runoff and sediment delivery from agricultural watersheds. J Environ Qual 32:927-936

Forest Practices Board (2000) Forest practices code. Forest Practices Board, Tasmania, Australia. Available at: http://www.fpa.tas.gov. au/fileadmin/user_upload/PDFs/Admin/FPC2000_Complete.pdf. Accessed 06 July 2007
Gomi T, Sidle RC, Noguchi S, Negishi JN, Abdul Rahim N, Sasaki S (2006) Sediment and wood accumulations in humid tropical headwater streams: effects of logging and riparian buffers. For Ecol Manage 224:166-175

Helmers MJ, Eisenhauer DE, Dosskey MG, Franti TG, Brothers JM, McCoullough MC (2005) Flow pathways and sediment trapping in a field-scale vegetative filter. Trans Am Soc Agr Eng 48:955-968

Hemstad NA, Merten EC, Newman RM (2008) Effects of riparian forest thinning by two types of mechanical harvest on stream fish and habitat in northern Minnesota. Can J Forest Res 38:247-256

Isbell R (1996) The Australian soil classification. CSIRO, Collingwood

Karr JR, Schlosser JJ (1978) Water resources and the land water interface. Science 201:229-234

Keenan RJ, Parsons M, Gerrand A, O'Loughlin E, Beavis S, Gunawardana D, Gavran M, Bugg A (2004) Plantations and water use: a review prepared for the Forest and Wood Products Research and Development Corporation. Bureau of Rural Sciences, Canberra

Keim RF, Schoenholtz SH (1999) Functions and effectiveness of silvicultural streamside management zones in loessial bluff forests. For Ecol Manage 118:197-209

Larson WE, Pierce PJ, Dowdy RH (1983) The threat of soil erosion to long-term crop production. Science 219:458-465

Lee P, Smyth C, Boutin S (2004) Quantitative review of riparian buffer width guidelines from Canada and the United States. J Environ Manage 70:165-180

Loch RJ, Espigares T, Costantini A, Garthe R, Bubb K (1999) Vegetative filter strips to control sediment movement in forest plantations: validation of a simple model using field data. Aust $\mathrm{J}$ Soil Res 27:929-946

Lowrance RR, Leonard R, Sheridan J (1985) Managing riparian ecosystems to control nonpoint pollution. J Soil Water Conserv 40:87-91

Lowrance R, Altier LS, Newbold JD, Schnabel RR, Groffman PM, Denver JM, Correll DL, Gilliam JW, Robinson JL, Brinsfield RB, Staver KW, Lucas W, Todd AH (1997) Water quality functions of riparian forest buffers in Chesapeake Bay watersheds. Environ Manage 21:687-712

Lynch JA, Corbett ES (1990) Evaluation of best management practices for controlling nonpoint pollution from silvicultural operations. Water Res Bull 26(1):41-52

Maltby L, Hills L (2008) Spray drift of pesticides and stream macroinvertebrates: experimental evidence of impacts and effectiveness of mitigation measures. Environ Pollut 156:1112-1120

Mander U, Hayakawa Y, Kuusemets V (2005) Purification processes, ecological functions, planning and design of riparian buffer zones in agricultural watersheds. Ecol Eng 24:421-432

Marlow CB, Pogacnik TM, Quinsey SD (1987) Stream bank stability and cattle grazing in southwestern Montana. J Soil Water Conserv 42(4):291-296

Mattson JA, Baumgras JE, Blinn CR, Thompson MA (2000) Harvesting options for riparian areas. In: Verry EL, Hornbeck JW, Dolloff CA (eds) Riparian management of forests of the continental eastern United States. Lewis Publishers, Boca Raton, pp 255-272

McDowell RW, Sharpley AN (2002) The effect of antecedent moisture conditions on sediment and phosphorus loss during overland flow: Mahantango Creek catchment, Pennsylvania, USA. Hydrol Process 16:3037-3050

McKergow LA, Weaver DM, Prosser IP, Grayson RB, Reed AEG (2003) Before and after riparian management: sediment and nutrient exports from a small agricultural catchment, Western Australia. J Hydrol 270:253-272

McKergow LA, Prosser IP, Weaver DM, Grayson RB, Reed AE (2006) Performance of grass and eucalyptus riparian buffers in a pasture catchment, Western Australia, part 1: riparian hydrology. Hydrol Process 20:2309-2326 
Mitsch WJ, Gosselink JG (2007) Wetlands. Wiley, New York

Neary DG (2002) Chapter 6: environmental sustainability of forest energy production, 6.3 Hydrologic values. In: Richardson J, Smith T, Hakkila P (eds) Bioenergy from sustainable forestry: guiding principles and practices. Elsevier, Amsterdam, pp 36-67

Neary DG, Hornbeck JW (1994) Chapter 4: impacts of harvesting practices on off-site environmental quality. In: Dyck WJ, Cole DW, Comerford NB (eds) International Energy Agency Project A6. Impacts of harvesting on long-term site productivity. Chapman and Hall, London, pp 81-118

Neary DG, Michael JL (1996) Herbicides-protecting long-term sustainability and water quality in forest ecosystems. New Zeal J For Sci 26:241-264

Neary DG, Bush PB, Michael JL (1993) Fate, dissipation, and environmental effects of pesticides in southern forests. Environ Toxicol Chem 12:411-428

O’Loughlin CL, Pearce AJ (1976) Influence of Cenozoic geology on mass movement and sediment yield response to forest removal. Bull Int Assoc Eng Geol 14:41-46

Palik BJ, Zasada JC, Hedman CW (2000) Ecological principles for riparian silviculture. In: Verry ES, Hornbeck JW, Doloff CA (eds) Riparian management of forests of the continental eastern United States. Lewis Publ, Boca Raton, pp 223-254

Phillips JD (1989) An evaluation of factors determining the effectiveness of water quality buffer zones. J Hydrol 107:133-145

Phillips MJ, Swift LW Jr, Blinn CR (1999) Chapter 16: best management practices for riparian areas. In: Verry ES, Hornbeck JW, Dolloff CA (eds) Riparian management in forests of the continental Eastern United States. CRC Press, Boca Raton, pp 273-286

Prosser IP, Rutherfurd ID, Olley JM, Young WJ, Wallbrink PJ, Moran CJ (2001) Large-scale patterns of erosion and sediment transport in river networks, with examples from Australia. Mar Freshw Res 521:81-99

Reid R, Burk L (2002) A web of trees. Available at: http://www. plantations2020.com.au/assets/acrobat/Web of trees 72.pdf. Accessed 24 August 2009

Reid LM, Dunne T (1984) Sediment production from forest road surfaces. Water Resour Res 20:1753-1761

Robins L (2002) Managing riparian land for multiple uses. RIRDC Publ, p 45

Schultz RC, Isenhart TM, Colletti JP, Simpkins WW, Udawatta RP, Schultz PL (2009) Chapter 8: riparian and upland buffer practices. In: Garrett HE (ed) North American agroforestry: an integrated science and practice, 2nd edn. Am Soc Agron, Madison, pp 163-218

Schumm SA, Harvey MD (1982) Natural erosion in the USA. In: Schmidt B (ed) Determinants of soil loss tolerance. Special Publication 45. Am Soc Agron, Madison, pp 23-39
Sidle RC, Sasaki S, Otsuki M, Noguchi S, Abdul Rahim N (2004) Sediment pathways in a tropical forest: effects of logging roads and skid trails. Hydrol Process 18:703-720

Sims C, Cotching W (2000) Turbidity and sediment loads from selected catchments in northwest Tasmania. Nat Res Manage 3:1-7

Smethurst P (2008) Summary of Australian codes of forest practice as they pertain to managing commercial plantations in stream-side buffers on cleared agricultural land. CRC Forestry Technical Report No. 178. Available at: http://www.crcforestry.com.au/publications/downloads/ TR178-Smethurst-FORPRINT.pdf. Accessed 24 August 2009

Specht A, West PW (2003) Estimation of biomass and sequestered carbon on farm forest plantations in northern New South Wales. Aust Biomass Bioenerg 25:363-379

Swanson RH, Golding DL, Rothwell RL, Bernier PY (1986) Hydrologic effects of clear-cutting at Marmot Creek and Streeter watersheds, Alberta. Info Rep NOR-X-278, North For Ctr, Can For Serv, Edmonton, Alberta, Canada

Swift LW Jr (1986) Filter strip widths for forest roads in the southern Appalachians. South J Appl For 10:27-34

Thompson D (2008) Plantations for Australia: the 2020 Vision Summary Progress Report. Available at: http://www.planta tions2020.com.au/assets/acrobat/2020\%20Vision\%20Progress $\%$ 20Summary\%20Report\%202008.pdfAccessed 07 July 2009

USDA ARS (1987) Stability design of grass-lined open channels. Agric Handb 667. US Dept Agric, Washington

Wasson RJ (1994) Annual and decadal variation of sediment yield in Australia, and some global comparisons. In: Olive LJ, Loughran RJ, Kresby JA (eds) Variability in stream erosion and sediment transport. IAHS Publ 224, IAHS Press, Wallingford, pp 139-148

Wasson RJ, Olive LJ, Rosewell CJ (1996) Rates of erosion and sediment transport in Australia. In: Walling DE, Webb B (eds) Erosion and sediment yield: global and regional perspectives. IAHS Publication 236, IAHS Press, Wallingford, pp 139-148

Welsch DJ (1991) Riparian forest buffers; function and design for protection and enhancement of water resources. USDA For Serv Northeastern Area State Private For Publ NA-PR-07-91. Available at: http://www.na.fs.fed.us/spfo/pubs/n_resource/buffer/cover.htm. Accessed 24 August 2009

Williams TM, Lipscomb DJ, English WR, Nickel C (2003) Mapping variable - width streamside management zones for water quality protection. Biomass Bioenerg 24:329-336

Zaimes GN, Schultz RC, Isenhart TM (2004) Stream bank erosion adjacent to riparian forest buffers, row-cropped fields, and continuously-grazed pastures along Bear Creek in central Iowa. J Soil Water Conserv 59:19-27

Ziemer RR, Ryan DF (2000) Current status of experimental paired watershed research in the USDA Forest Service. Trans Am Geophys Union 81(48):F380 